\title{
RESEARCH
}

Open Access

\section{A role for human brain pericytes in neuroinflammation}

Deidre Jansson ${ }^{1,2,4}$, Justin Rustenhoven ${ }^{1,4}$, Sheryl Feng ${ }^{1,2,4}$, Daniel Hurley ${ }^{5}$, Robyn L Oldfield ${ }^{6}$, Peter S Bergin ${ }^{4,7}$, Edward W Mee ${ }^{4,7}$, Richard LM Faull ${ }^{3,4}$ and Mike Dragunow ${ }^{1,2,4^{*}}$

\begin{abstract}
Background: Brain inflammation plays a key role in neurological disease. Although much research has been conducted investigating inflammatory events in animal models, potential differences in human brain versus rodent models makes it imperative that we also study these phenomena in human cells and tissue.
\end{abstract}

Methods: Primary human brain cell cultures were generated from biopsy tissue of patients undergoing surgery for drug-resistant epilepsy. Cells were treated with pro-inflammatory compounds IFNY, TNFa, IL-1 $\beta$, and LPS, and chemokines IP-10 and MCP-1 were measured by immunocytochemistry, western blot, and QRT-PCR. Microarray analysis was also performed on late passage cultures treated with vehicle or IFNY and IL-1ß.

Results: Early passage human brain cell cultures were a mixture of microglia, astrocytes, fibroblasts and pericytes. Later passage cultures contained proliferating fibroblasts and pericytes only. Under basal culture conditions all cell types showed cytoplasmic NFKB indicating that they were in a non-activated state. Expression of IP-10 and MCP-1 were significantly increased in response to pro-inflammatory stimuli. The two chemokines were expressed in mixed cultures as well as cultures of fibroblasts and pericytes only. The expression of IP-10 and MCP-1 were regulated at the mRNA and protein level, and both were secreted into cell culture media. NFkB nuclear translocation was also detected in response to pro-inflammatory cues (except IFNY) in all cell types. Microarray analysis of brain pericytes also revealed widespread changes in gene expression in response to the combination of IFNY and IL-1 $\beta$ treatment including interleukins, chemokines, cellular adhesion molecules and much more.

Conclusions: Adult human brain cells are sensitive to cytokine challenge. As expected 'classical' brain immune cells, such as microglia and astrocytes, responded to cytokine challenge but of even more interest, brain pericytes also responded to such challenge with a rich repertoire of gene expression. Immune activation of brain pericytes may play an important role in communicating inflammatory signals to and within the brain interior and may also be involved in blood brain barrier (BBB) disruption. Targeting brain pericytes, as well as microglia and astrocytes, may provide novel opportunities for reducing brain inflammation and maintaining BBB function and brain homeostasis in human brain disease.

Keywords: Microglia, Astrocytes, Inflammation, Blood-brain barrier, Chemokines

\footnotetext{
* Correspondence: m.dragunow@auckland.ac.nz

'Department of Pharmacology and Clinical Pharmacology, The University of

Auckland, 85 Park Road, Auckland 1023, New Zealand

${ }^{2}$ Gravida National Centre for Growth and Development, The University of

Auckland, Bldg 505, 85 Park Road, Auckland 1023, New Zealand

Full list of author information is available at the end of the article
} 


\section{Introduction}

Brain inflammation occurs in a number of neurological (for example, epilepsy, Alzheimer's disease, Parkinson's disease, motor neuron disease) and psychiatric (schizophrenia, depression) diseases and is generally thought to worsen disease symptoms and progression [1]. Although many different brain cells are likely to be involved in brain inflammation, most attention has focused on the role of nonnerve brain cells, especially microglia and astrocytes [2-4]. More recently, there has been an appreciation that perivascular cells may also be involved in brain inflammation. In particular, brain pericytes which surround endothelial cells and are critical in the development and maintenance of the blood brain barrier (BBB) may be targets as well as effectors of brain inflammatory processes $[5,6]$. Pericytes interact dynamically with astrocytes and microglia and can also receive signals from the periphery resulting in central nervous system (CNS) inflammatory molecule production $[7,8]$.

CNS pericytes are also in a pivotal position to mediate interactions between systemic and central brain inflammation [9] and have been shown to play a role in recruitment of peripheral immune cells to the brain [10-12]. The further increase in brain infiltration of systemic immune molecules and cells as well as other blood components may directly cause neuronal damage and/or promote microglial inflammation [13].

For the above reasons, targeting systemic and central brain inflammatory pathways for treating brain disorders is a high priority for neuropharmacological drug development. Most of this work has been undertaken using animal models and given potential species differences more work needs to be undertaken to identify pathways specifically involved in human brain inflammation $[14,15]$. In this regard, mixed in vitro cultures from adult human brain tissue have been characterized by several groups [16-18]. However, until recently, the exact composition of these cultures has been unclear. Previous work in our group has revealed that a mixed population of astrocytes, microglia and fibroblast-like cells can be generated from adult human brain cultures $[17,19]$. More recently, we and others have identified a proportion of the fibroblast-like cells as human brain pericytes $[5,19,20]$. Many previous in vitro models of the $\mathrm{BBB}$ involve the use of animal or transformed human pericytes and brain microvascular endothelial cells [21]. We sought to investigate the effects of inflammatory molecules on primary adult human brain-derived cells (pericytes, astrocytes and microglia) that are in key locations for communicating inflammatory signals to and within the brain.

\section{Methods}

Reagents

DMEM/F12, fetal bovine serum (FBS) and PenStrep glutamine (PSG) were obtained from Gibco/Life Technologies
(Carlsbad, CA, USA). Other reagents included human recombinant IFNY (R\&D Systems, Minneapolis, MN, USA), IL-1 $\beta$, TNF $\alpha$ (PeproTech, Rocky Hill, NJ, USA), Triton ${ }^{\text {tw }}$ X-100, Tween ${ }^{\circ} 20$, chloroform, lipopolysaccharide (LPS) and Hoechst 33528, and ExtrAvidin ${ }^{\circ}$-peroxidase (Sigma, St. Louise, MO, USA), TRIzol ${ }^{\circ}$ (Ambion/Life Technologies, Carlsbad, CA, USA) and enhanced chemiluminescence (ECL) detection reagents (Amersham/GE Healthcare, Buckinghamshire, England).

\section{Biopsy brain tissue}

Human middle temporal gyrus was obtained, with informed consent, from surgeries of patients with drug-resistant temporal lobe epilepsy, and with the approval of the Northern Regional Ethics Committee (New Zealand).

\section{Isolation of mixed glial cultures from human brain tissue}

Brain tissue from the middle temporal gyrus (MTG), obtained following epilepsy surgery, was processed for the isolation and culture of microglia, astrocytes and brain pericytes, as previously described [19]. Cells were incubated at $37^{\circ} \mathrm{C}$ with $5 \% \mathrm{CO}_{2}$ until seeding for experiments, approximately four to five days. Once mixed cultures reached the desired confluency, flasks were trypsinized with $0.25 \%$ trypsin-ethylenediaminetetraacetic acid (EDTA) and scraped to obtain microglia and astrocytes. Cells were seeded into 96-well plates at 5,000 cells/well in complete media (DMEM/F12 with 10\% FBS and 1\% PSG (penicillin $100 \mathrm{U} / \mathrm{ml}$, streptomycin $100 \mu \mathrm{g} / \mathrm{ml}$, L-glutamine 0.29 $\mathrm{mg} / \mathrm{ml})$ ) and were used for experiments one to three days later. Experiments performed on mixed glial cultures were at passage 2 for all experiments in this study.

For further culture of primary cells, cells from passage 5 up to passage 9 were microglia- and astrocyte-free cultures and are referred to as pericytes throughout the text [17]. These cells were kept in complete media and were used directly or frozen in 5\% dimethyl sulfoxide (DMSO), 95\% FBS for later culture. Although many rodent studies derive pericytes from isolated blood vessels, consistent with our work, human brain studies have generally derived pericytes from dissociated grey matter $[5,20]$.

Leptomeningeal explant cultures were obtained by removing meninges from MTG brain tissue and rinsing with complete media. Meninges were cut into small pieces, 2 to $3 \mathrm{~mm}^{2}$, and put into six-well plates containing $850 \mu \mathrm{l}$ media/well, four to five pieces/well, and incubated at $37^{\circ} \mathrm{C}$, $5 \% \mathrm{CO}_{2}$ in complete media. Tissue was cultured with such low volumes of media so that it would remain stationary in the well. Media was changed after 48 to 72 hours in culture and every three to four days afterwards. Depending on cases, normally around one to two weeks in culture, cells began to migrate out from explants. After two to three weeks in culture, explants were moved to a new six-well plate to continue culture. Cells were generated from the 
explants again. This procedure was continued and explants were moved once underlying cells became confluent.

\section{Cell treatments}

Cells were treated for the indicated times with IFNy, IL- $1 \beta$ and LPS, each at $10 \mathrm{ng} / \mathrm{ml}$, TNF $\alpha$ at $50 \mathrm{ng} / \mathrm{ml}$, unless otherwise stated, or vehicle $(0.1 \%$ BSA in phosphate buffered saline (PBS)).

\section{Immunocytochemistry}

At endpoint, cells were fixed using $4 \%$ paraformaldehyde solution. After washing in PBS with $0.2 \%$ Triton X-100 (PBS-T), plates were incubated with primary antibodies overnight at $4^{\circ} \mathrm{C}$ (all antibodies were diluted in goat immunobuffer ( $1 \%$ goat serum, $0.2 \%$ Triton $\mathrm{X}-100^{\mathrm{mit}}$, and $0.04 \%$ thiomersal in PBS)). Dilutions of antibodies are listed in Additional file 1: Table S1. Plates were washed again in PBS-T and incubated with secondary antibodies two to three hours at room temperature, then rinsed. For fluorescent staining, nuclei were detected using Hoechst stains. Otherwise, plates were incubated with ExtrAvidin-peroxidase diluted 1/500 in goat immunobuffer for one hour at room temperature then detected using 3,3'-diaminbenzidine. Discovery-1 Automated Fluorescence Microscope (Molecular Devices, Sunnyvale, CA, USA) or ImageXpress ${ }^{\circ}$ Micro XLS (Version 5.3.0.1, Molecular Devices) housed at the Biomedical Imaging Research Unit, University of Auckland was used for image acquisition from micro-well plates [22]. Quantitative analysis of positively stained cells and total cells was performed using Metamorph ${ }^{\circ}$ software (Version 6.2.6, Molecular Devices) [23] using the Cell Scoring module for interferon inducible protein 10 (IP-10) and monocyte chemotactic protein-1 (MCP-1) expression or MetaXpress ${ }^{\circ}$ software (Version 5.3.0.1, Molecular Devices) for Multiwavelength Cell Scoring of co-labelling. Each condition was done in triplicate and four images/well were analyzed, with approximately 250 to 400 cells/field counted.

\section{Western blot}

At endpoint, cells were rinsed with PBS and scraped into Eppendorf tubes. Cells were centrifuged and the pellet was resuspended in lysis buffer $(25 \mathrm{mM}$ Tris- $\mathrm{HCl} \mathrm{pH}$ 7.5, $150 \mathrm{mM} \mathrm{NaCl}, 50 \mathrm{mM} \mathrm{NaF}, 0.5 \mathrm{mM}$ EDTA pH 8, $0.5 \%$ Triton-X $100^{\text {max }}, 5 \mathrm{mM} \beta$-glycerophosphate, with fresh $1 \mathrm{mM}$ dithiothreitol (DTT), $1 \mathrm{mM}$ phenylmethanesulfonyl fluoride (PMSF), $1 \mathrm{mM} \mathrm{Na}_{3} \mathrm{VO}_{4}$ ). A total of 10 to $20 \mu \mathrm{g}$ protein diluted in Laemmli buffer $(125 \mathrm{mM}$ Tris- $\mathrm{HCl}, \mathrm{pH}$ $6.8,5 \%$ glycerol, $4 \%$ sodium dodecyl sulfate (SDS), $0.2 \%$ bromophenol blue) was separated on $4 \%$ to $12 \%$ pre-cast gels (Life Technologies) and separated by SDS-polyacrylamide gel electrophoresis (SDS-PAGE). Media samples for Western blot were collected and centrifuged to remove debris. Supernatants were transferred to new tubes and diluted in Laemmli buffer and separated on SDS-PAGE as above.

Fluorescent western blots were carried out as previously described [24]. Briefly, proteins were transferred to polyvinylidene difluoride (PVDF) membranes from Millipore (Billerica, MA, USA)(IPFL00010 Immobilon-FL 0.45 mm) for optimal fluorescence signal and blocked in Odyssey Blocking Buffer (Li-COR 927-40000) diluted 1:1 in Tris buffered saline with $0.1 \%$ Tween $^{\circ}-20$ (TBS-T), for one hour at room temperature. Membranes were incubated with primary antibodies [see Additional file 1: Table S1] diluted in Odyssey Blocking Buffer and TBS-T (1:1) overnight at $4^{\circ} \mathrm{C}$. Membranes were incubated with secondary antibodies from Li-COR diluted in Odyssey and TBS-T (1:1) with $0.1 \%$ Tween -20 and $0.02 \%$ SDS for two hours at room temperature. Images were captured using the $\mathrm{Li}$ COR imaging system. Conversely, for chemiluminescent western blots the signal was detected using ECL detection reagents (Amersham) and visualized using the Bio-Rad ChemiDoc $^{\text {Tw }}$ imaging system.

\section{Quantitative RT-PCR}

Quantitative reverse transcriptase polymerase chain reaction (qRT-PCR) was performed as described previously [19]. At endpoint, cells were rinsed $2 \times$ with PBS then TRIzol $^{\circ}$ ( $1 \mathrm{ml} /$ well) was added and lysates were transferred to screw cap tubes. Chloroform $(200 \mu \mathrm{l})$ was added and tubes were shaken to mix. Samples were centrifuged, the aqueous layer was transferred to a new tube and an equal volume of $70 \%$ ethanol (EtOH) was added. RNA was then extracted using RNeasy kits (Qiagen Inc. Venlo, Limburg, Nethlands). cDNA was made from $3 \mu \mathrm{g}$ DNase-1 (Promega, Madison, WI, USA) treated RNA using the Superscript III first strand synthesis kit (Invitrogen, Calrsbad, CA, USA). qRT-PCR was performed using Platinum SYBR Green qPCR SuperMix-UDG with Rox kit (Invitrogen). Standard curves were performed for all primers used; sequences and efficiencies are included in Additional file 2: Table S2. The level of gene expression was normalized to GAPDH at time zero or untreated conditions using the $\Delta \mathrm{C}_{\mathrm{t}}$ method [25].

\section{Microarray experiment}

Five cases from epilepsy tissue were chosen for this experiment, all male, with an average age of $45+/-7$ years, with varying degrees of mesial temporal sclerosis. All cultures were frozen down in 5\% DMSO in FBS at passage 3 or 4 after initial isolation. Cells were thawed from liquid nitrogen quickly at $37^{\circ} \mathrm{C}$. Cells were transferred to $15 \mathrm{ml}$ conicals with fresh pre-warmed complete DMEM/F12 and centrifuged to pellet cells. Cells were resuspended in $15 \mathrm{ml}$ complete DMEM/F12 and transferred to T75 tissue culture flasks. Cells were incubated for three days to enable $80 \%$ to $90 \%$ confluency to be reached. Cells were 
trypsinized as indicated for human brain cell tissue culture and seeded (passage 5) into six-well plates at $1.37 \times 10^{5}$ cells/well in complete DMEM/F12 and incubated at $37^{\circ} \mathrm{C}$, $5 \% \mathrm{CO}_{2}$ for two days. Cells were treated with vehicle (0.1\% BSA in PBS) or IFN $\gamma$ and IL-1 $\beta$ at a final concentration of $10 \mathrm{ng} / \mathrm{ml}$ for 24 hours, three wells of a six-well plate per treatment per case. At endpoint, cells in six-well plates were rinsed two times with PBS and lysed with TRIzol $^{\oplus}$ reagent. Triplicate wells were pooled and stored in screw cap tubes at $-80^{\circ} \mathrm{C}$ until ready for RNA extraction. RNA extraction was carried out as above for qRT-PCR experiments. RNA quality was analyzed using the Experion ${ }^{\text {Ts }}$ System (BIO-RAD, Hercules, CA, USA) and the Experion ${ }^{\mathrm{TM}}$ RNA StdSens Analysis Kit. RNA was then labelled and hybridized to Affymetrix Genechip ${ }^{\circ}$ PrimeView $^{\mathrm{TM}}$ Human Gene Expression Arrays (Santa Clara, CA, USA) according to the manufacturer's instructions.

\section{Statistical analysis}

Individual experiments were repeated at least three times with cells derived from separate cases. Each condition was performed in triplicate and mean $+/$-standard deviation is presented from representative experiments. Statistical analysis was performed on replicates within experiments using one-way analysis of variance (ANOVA) and Dunnett's multiple comparison tests for significance with GraphPad Prism $^{\circledast}$ analysis software.

For the microarray analysis, PrimeView ${ }^{\mathrm{TM}}$ array data in CEL file format was read using the 'affy' package in the statistical language $\mathrm{R}$ and normalized using the robust multi-array (RMA) method. Quality assurance (QA) of the data showed that it was of good quality and free of obvious artefacts or outliers. The 'limma' package was used to compare differential expression between the control (vehicle-treated) and IFN $\gamma / \mathrm{IL}-1 \beta$-treated samples. Benjamini-Hochberg false-discovery rate control was used to adjust for multiple testing.

\section{Results}

Composition and inflammatory state of primary cells from adult human brain

Immunocytochemical analysis of dissociated cells from MTG after two weeks in culture revealed a mixed population of cells (referred to from now on as 'mixed glial cultures'). Positive staining for fibronectin and prolyl-4 hydroxylase $(\mathrm{P} 4 \mathrm{H})$ (fibroblast markers), platelet-derived growth factor receptor-beta (PDGFR- $\beta$ ), NG2 and alpha smooth muscle actin ( $\alpha$ SMA) (pericyte markers), CD45 (microglial cell marker), and glial fibrillary acidic protein (GFAP, astrocyte marker) was seen in early passages of dissociated cultures (Figure 1A-G). No endothelial cells were detected in any of our cultures using CD31 (data not shown). Composition of the mixed glial cultures varies from case to case, but we see 1-5\% GFAP positive cells and $15 \%$ to $25 \%$ CD45 positive cells. In this initial culture, there are approximately $80 \%$ of cells that stain positively for both $\alpha$ SMA and PDGFR $\beta$ (Figure $1 \mathrm{H}$ ). After subsequent passaging, CD45 and GFAP positive cells were lost and only the proliferating fibroblast-like and pericyte-like cells remained [26]. All cells in the later cultures are positive for fibronectin, and approximately 90\% of cells are positive for both $\alpha$ SMA and PDGFR $\beta$ (Figure $1 \mathrm{H}$ ). For purposes of simplicity, late passage cultures will be referred to as pericytes for the remainder of the manuscript. Considering the expression of fibroblast and pericyte specific markers it is likely that these dividing underlying cells derive from the meninges and brain microvasculature. To test this hypothesis, we resected the leptomeninges from the brain tissue and cultured them separately from the MTG cells. These explants were able to grow and divide in culture and generate new cells that migrate out of and away from the explant (unpublished observations). Positive staining for fibronectin, $\mathrm{P} 4 \mathrm{H}, \alpha \mathrm{SMA}$ and PDGFR- $\beta$ (Figure 2) was consistent with MTG cultures. Expression of both $\alpha$ SMA and PDGFR- $\beta$ were confirmed in the MTG and explant cultures by western blot analysis showing one specific band at the expected molecular weight [see Additional file 3: Figure S1]. The NG2 antibody detected two bands which were expressed in both MTG and explant cultures [see Additional file 3: Figure S1].

Translocation of nuclear factor light chain enhancer of activated B cells $(\mathrm{NF} \kappa \mathrm{B})$ is often used as a marker of a pro-inflammatory response. We examined NFkB p65 by immunocytochemistry in the mixed glial cultures treated with either vehicle, IFN $\gamma$, TNF $\alpha$, IL-1 $\beta$, or LPS to induce a pro-inflammatory response. Positive staining for $\mathrm{NF}_{k} \mathrm{~B}$ was observed in the cytoplasm under control conditions after two hours of vehicle treatment. Treatment with TNF $\alpha$, IL- $1 \beta$ or LPS induced translocation of NFKB to the nucleus in CD45, GFAP and $\alpha$ SMA positive cells [see Additional files 4, 5, 6: Figures S2, S3 and S4 respectively]. This result indicates that under our standard basal cell culture conditions adult human brain cells are in a 'resting' non-immunologically-activated state, making them a powerful system for studying human brain inflammation.

\section{Combination of IFN $\gamma$ and IL-1 $\beta /$ TNFa synergistically induces IP-10 but not MCP-1 expression and secretion in mixed glial cultures}

Previously, we have identified chemokines IP-10 and MCP-1 as being released into media from our mixed glial cultures as well as our pericyte cultures specifically in response to IFNy treatment [27]. Confirmation of this result in mixed glial cultures by quantitative immunocytochemistry revealed an increase in IP-10 and MCP-1 expression in response to IFN $\gamma$ treatment as demonstrated 


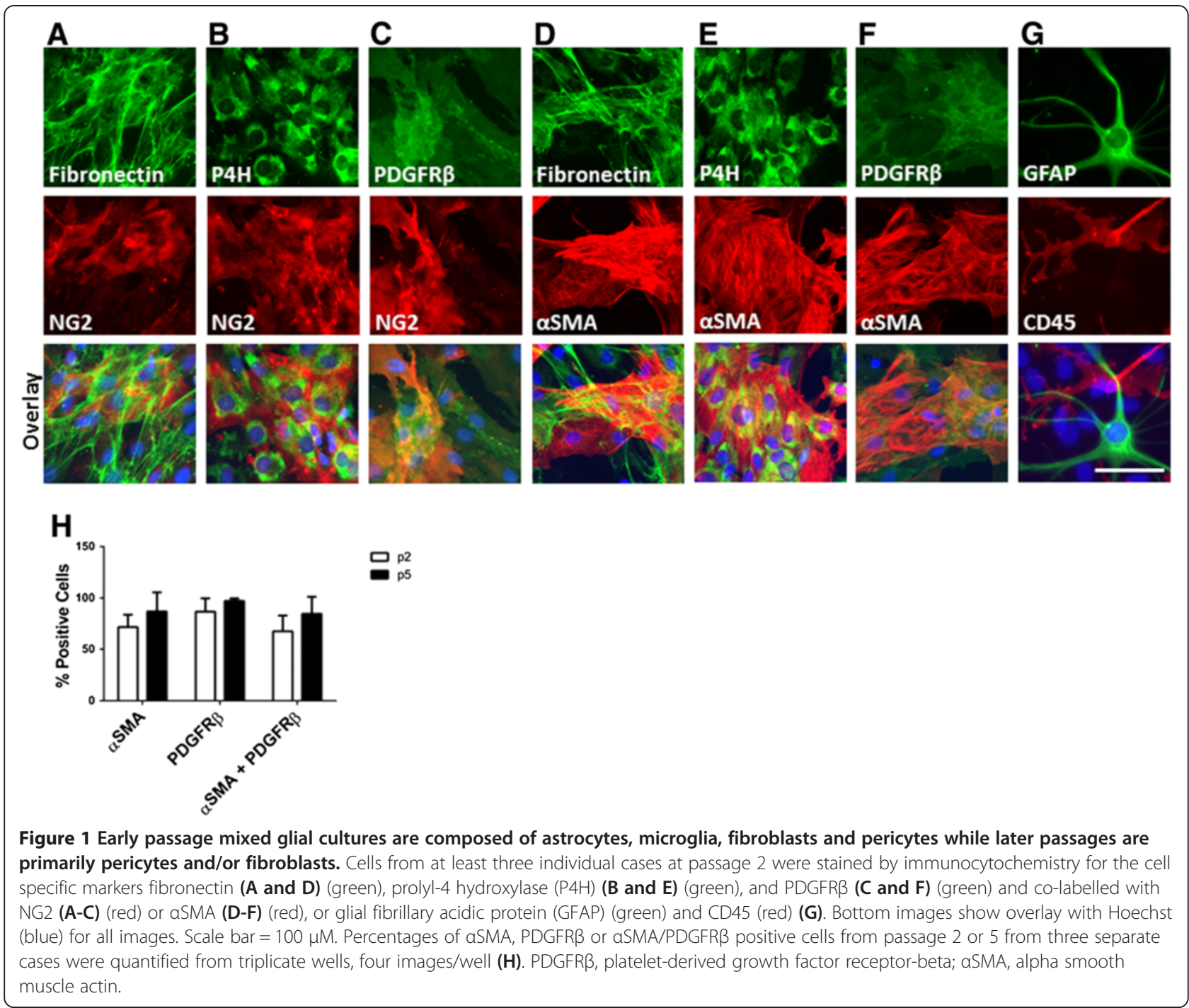

in Figure 3. We also tested the induction of IP-10 and MCP-1 protein expression in response to TNF $\alpha$, IL-1 $\beta$ and LPS. We found a concentration dependent increase in both chemokines after IFN $\gamma$, TNF $\alpha$ and LPS treatment but only MCP-1 was induced by IL- $1 \beta$ (Figure 3 ). It is also important to note that basally IP-10 expression was not detectable, while MCP-1 expression was found in $25 \%$ to $40 \%$ of cells in untreated conditions.

An inflammatory condition will rarely constitute the upregulation of a single cytokine, but many cytokines, chemokines and other inflammatory molecules [28,29]. We, therefore, examined the response of our mixed glial

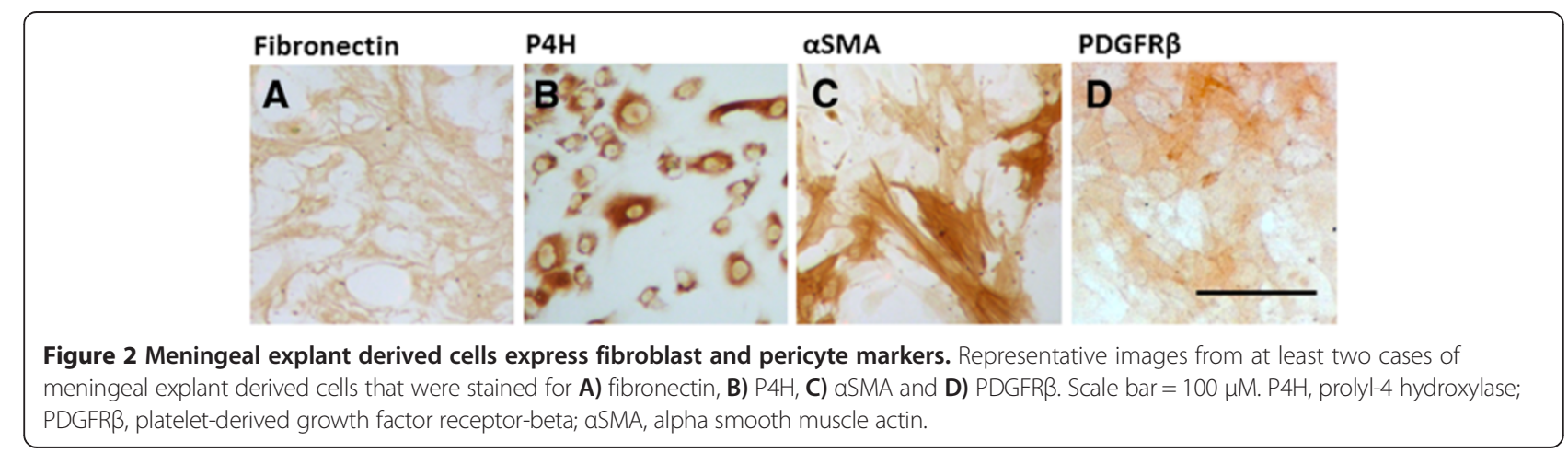



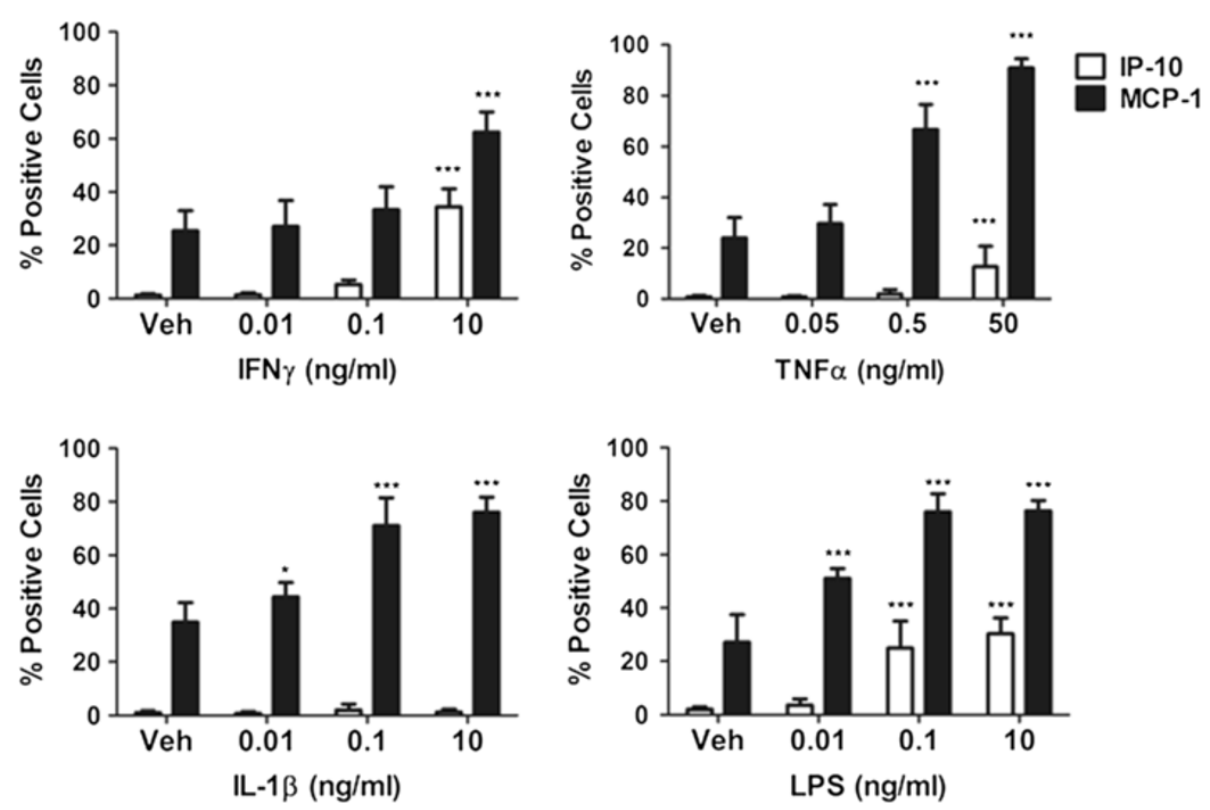

Figure 3 Mixed glial cultures express chemokines IP-10 and MCP-1 when stimulated with pro-inflammatory molecules. Quantification of cells immunocytochemically positive for IP-10 or MCP-1 in mixed glial cultures after 24 hours treatment with vehicle (0.1\% BSA in PBS), interferon Y (IFN $)$, tumor necrosis factor a (TNFa), interleukin $1 \beta(\mathrm{IL}-1 \beta)$ or lipopolysaccharide (LPS). Values plotted are percentages of total cells as measured by Hoechst positive cells from triplicate wells, four images per well. Data are representative of results from three separate cases. *indicates significance $(P<0.01)$, ***indicates significance $(P<0.0001)$. IP-10, interferon inducible protein-10; MCP-1, monocyte chemotactic protein-1.

cultures to a combination of IFN $\gamma$ and TNF $\alpha$, IL-1 $\beta$, or LPS treatment. Immunocytochemical examination of IP-10 in the mixed glial cultures revealed a synergistic increase in the number of cells expressing IP-10 when IFN $\gamma$ was combined with either TNF $\alpha$ or IL-1 $\beta$ treatment (Figure 4A). Interestingly, although the combination of IFN $\gamma$ and LPS increased the number of cells expressing IP-10 by only $20 \%$ above LPS alone, there was a further four-fold increase in the intensity of IP-10 staining by the combination, indicating a strong synergistic increase in overall protein expression per cell (Figure 4B). When we co-labelled with cell specific markers for microglia (CD45), astrocytes (GFAP) or pericytes ( $\alpha$ SMA) we could also detect an increase in expression of IP-10 in each cell type, although the effect of combining LPS and IFN $\gamma$ seems to be pericyte specific (Figures 4C, 5, 6, and 7). There was no significant change in the total number of astrocytes or microglia in response to any of the treatments (data not shown). MCP-1 expression was also increased in mixed glial cultures in response to pro-inflammatory stimuli; however, this also appears to be pericyte specific as basal expression of MCP-1 is detected in $90 \%$ to $100 \%$ of all microglia and astrocytes in these cultures under basal conditions (Figures 8, 9, 10 and 11). Moreover, the synergy seen with IP-10 expression by combining treatments is not present in the MCP-1 response.
Brain pericytes respond to inflammatory cues by activating pro-inflammatory pathways in the absence of microglia and astrocytes

Although pericytes expressed IP-10 and MCP-1 in response to immune activators the contribution of co-cultured microglia and/or astrocytes to this response was not clear. Therefore, we tested late passage cultures in which microglia and astrocytes were absent. Treatment of pericytes with TNF $\alpha$, IL-1 $\beta$ and LPS, but not IFN $\gamma$, showed clear nuclear translocation of NFkB p65 by immunocytochemistry after two hours (Figure 12).

Previous studies have shown the brain meninges to play a vital role in communication of inflammatory responses across the $\mathrm{BBB}$ [30-33]. We investigated the ability of meningeal explant cultures to respond to inflammatory stimuli. LPS and IL-1 $\beta$ but not IFN $\gamma$ treatment induced $\mathrm{NF}$ B B translocation [see Additional file 7: Figure S5], which is consistent with our experiments in mixed glial and pericyte cultures. Furthermore, treatment with IFNy induced IP-10 expression with LPS and IL- $1 \beta$ producing little or no effect, while MCP-1 expression was induced by all three treatments, IFN $\gamma$, IL-1 $\beta$ and LPS in our explant cultures [see Additional file 7: Figure S5].

Pericyte cultures responded similarly to the cytokine treatment in the absence of microglia or astrocytes. We examined IP-10 and MCP-1 expression by western blot 


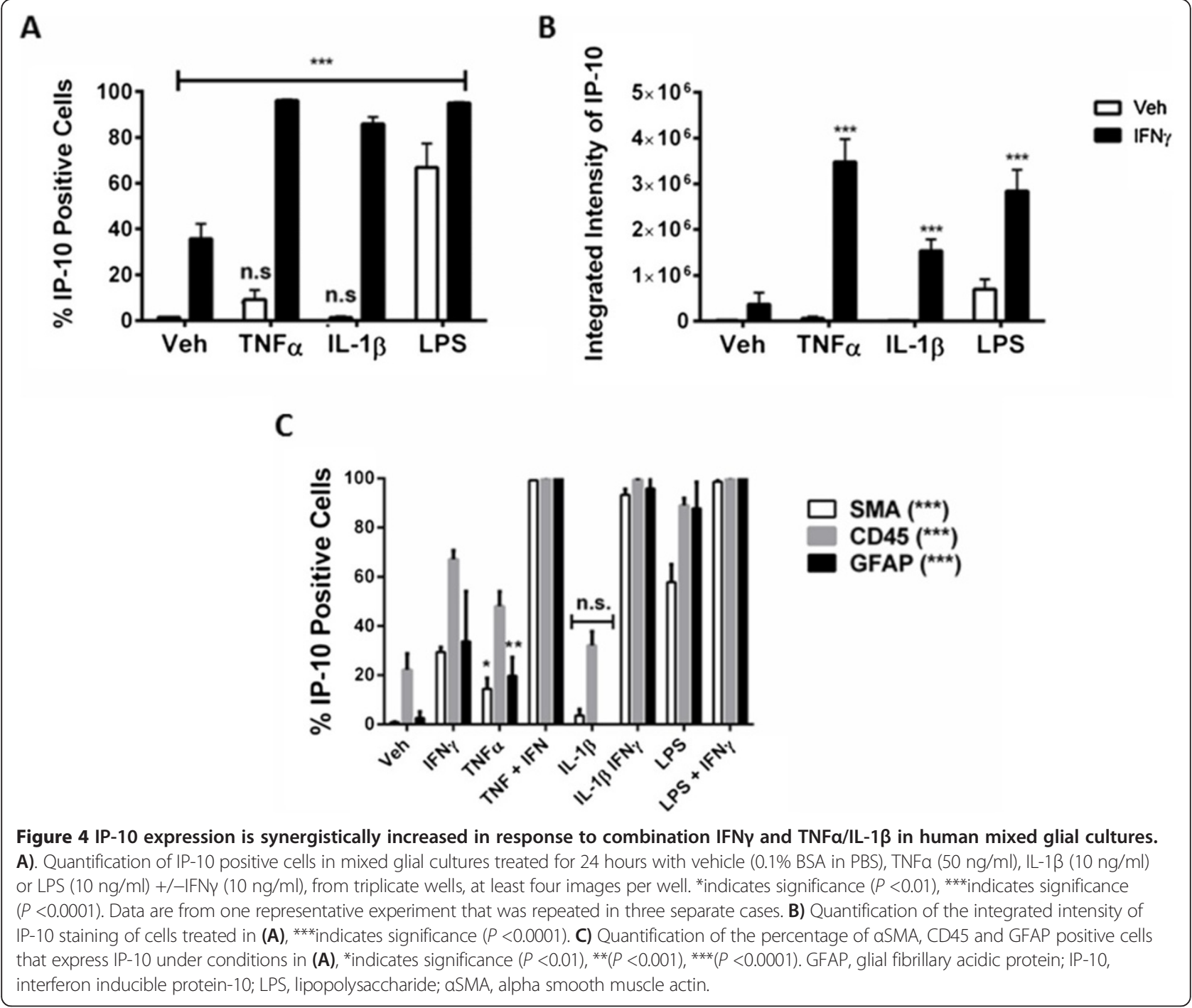

of cell lysates and conditioned media and could see the same synergy of IP-10 induction in response to IFN $\gamma+$ TNF $\alpha$, or IFN $\gamma+$ IL-1 $\beta$ compared to the cytokines alone (Figure 13A). It is noteworthy to mention that we did not see similar induction of IP-10 in response to LPS in pericytes alone compared to pericytes in mixed glial cultures. However, despite little to no induction of IP-10 by either IFN or LPS alone, we saw a significant increase in IP-10 protein expression and secretion in response to IFN and LPS together. This indicated that the concentration of LPS used was not saturating the system and indeed was within the range published in several other studies [34-37]. Consistent with previous results we see that basally MCP-1 is expressed at a higher level than IP-10. MCP-1 is also released into media under basal conditions and this is increased in response to IFN $\gamma$, TNF $\alpha$, IL-1 $\beta$ and LPS and with combination treatment.
To confirm the cell types responsible for chemokine release we performed immunocytochemistry on pericyte cultures treated with IFN $\gamma$ and IL-1 $\beta$. Our data showed that cells positive for MCP-1 and IP-10 in response to IFN $\gamma$ and IL-1 $\beta$ are also positive for the pericyte marker aSMA (Figure 13B).

A time-dependent increase in both MCP-1 and IP-10 secretion by pericytes was seen by western blot analysis in response to IFN $\gamma+\mathrm{TNF} \alpha$, IL- $1 \beta$ or LPS treatment [see Additional file 8: Figure S6], which is consistent with immunocytochemical data (Figure 14A and B). IP-10 protein expression was induced in a time-dependent manner in pericytes by IFNY and combined treatments, while MCP-1 was induced by all treatments. Accompanying the increase in protein expression was a sustained increase in secretion lasting at least 72 hours for IP-10 and 96 hours for MCP-1. We also examined the 


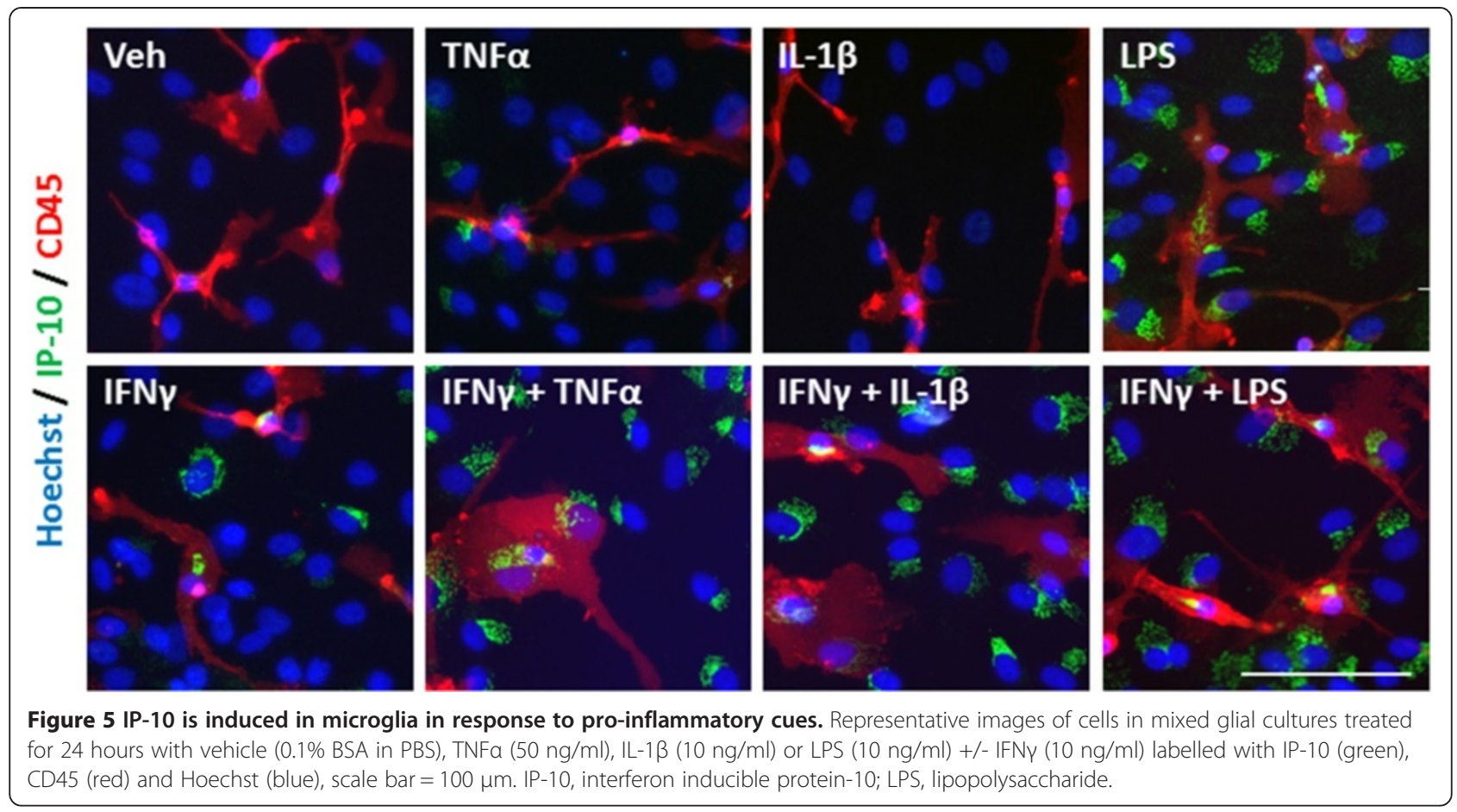

time-dependent regulation of IP-10 and MCP-1 in our pericyte culture system at the mRNA level by qRT-PCR [see Additional file 8: Figure S6]. Our results have shown that IP-10 and MCP-1 mRNA were present at extremely low levels, if at all, under basal conditions. However, mRNA expression was quickly induced by treatment with the inflammatory stimuli IFN $\gamma$ and IL-1 $\beta$. IP-10 mRNA was increased at one hour by almost 1,000-fold compared to vehicle control, with a maximum between 8 and 24 hours. MCP-1 was induced to a lesser extent, but by no means trivial at more than 10 -fold after only 30 minutes treatment.

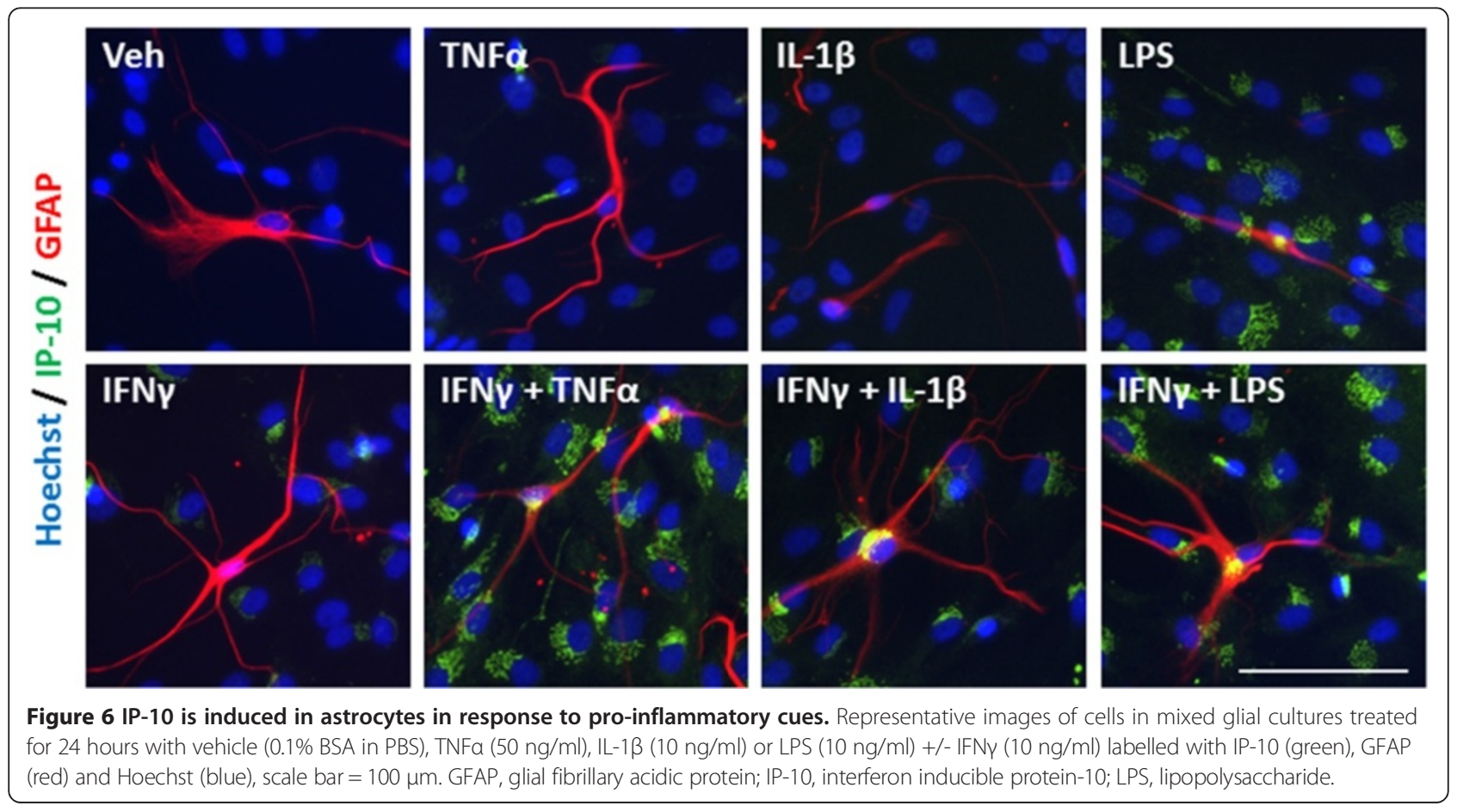




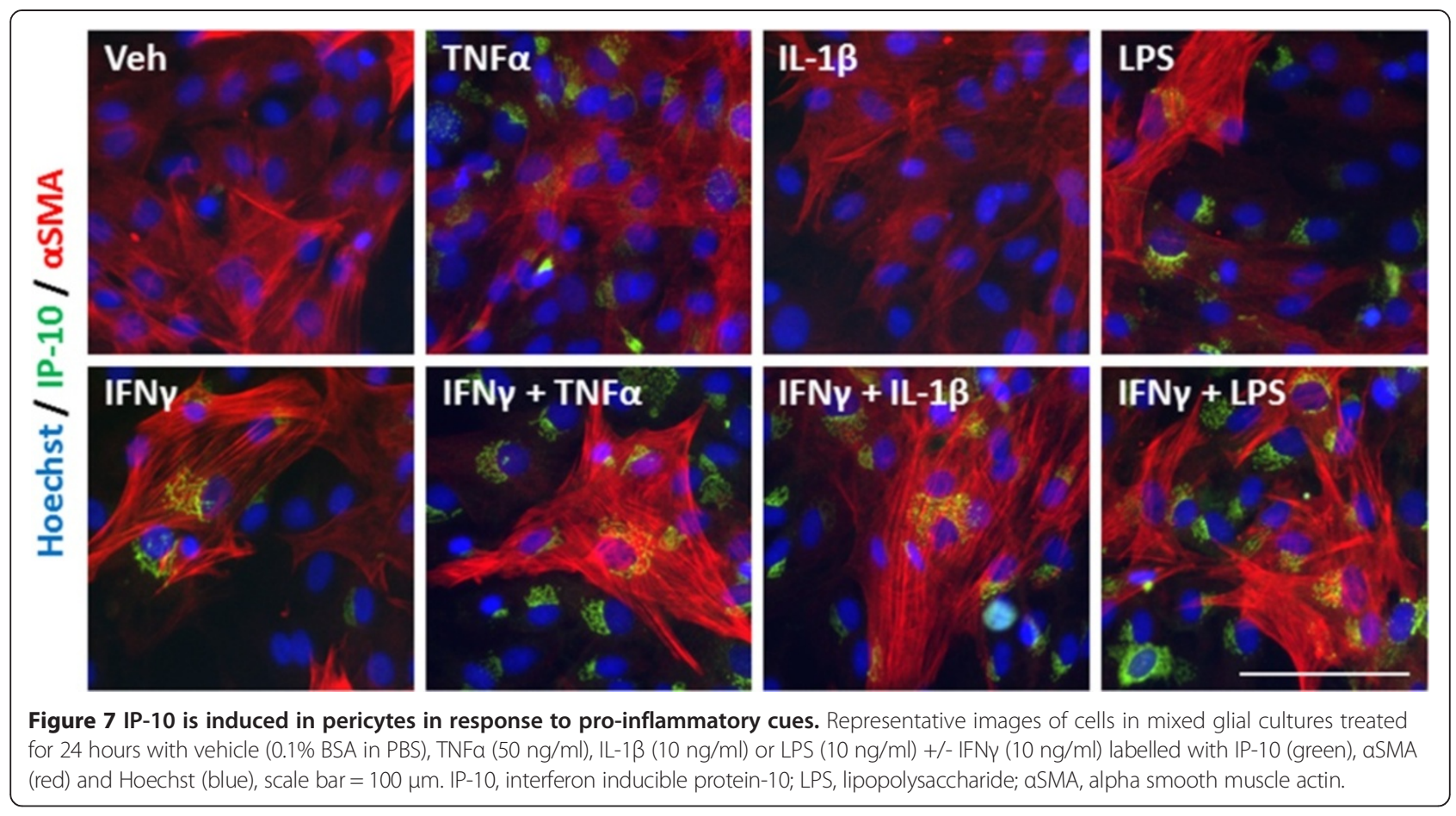

\section{Genome wide expression changes of immune pathways in human brain pericyte cultures}

Since our qRT-PCR data revealed that treatment with the pro-inflammatory cytokines IFN $\gamma+$ IL-1 $\beta$ could induce gene expression of the chemokines IP-10 and MCP-1, we sought to identify other regulatory mechanisms at the level of transcription in our pericyte cultures. The purpose of this experiment was to determine the initial changes in gene expression of pericytes in the absence of microglia or astrocytes. Cells from five separate cases were obtained with an age range of $45+/-7$ years, all male. Cells were treated with vehicle or IFN $\gamma+$ IL-1 $\beta$ for 24 hours, a combination of cytokines modelling pathological events [38]. RNA was extracted and submitted for microarray analysis using Affymetrix Primeview arrays.

Primary analysis of microarray data confirmed the increased expression of both IP-10 and MCP-1 in response to IFN $\gamma$ and IL-1 $\beta$ treatment. We also observed a significant increase in a plethora of genes involved in the immune response including interleukins (IL-6, IL-8, IL-32), chemokines (CXCL9, CXCL10, CXCL11, CCL2, CCL8), intracellular adhesion molecules (ICAM, VCAM), superoxide dismutase (SOD2), and apolipoprotein L (APOL1, APOL2, APOL3, APOL4, APOL6) by initial microarray analysis and by plotting raw data for individual genes [see Additional file 9: Figure S7]. Pathway analysis using the Gather online tool (http://gather.genome.duke.edu/) revealed enrichment for genes involved in immune response, complement activation, response to stress and chemotaxis (Table 1). Interestingly, and reassuringly, all five cases showed a very similar gene expression profile under control and induced conditions.

Although the general response of the primary cells to IFN $\gamma$ and IL-1 $\beta$ was to increase gene expression, there was also downregulation of several genes including tumor necrosis factor receptor super family member 10D (TNFRSF10D, involved in inhibition of apoptosis [39]) CXCL12 (expressed in embryonic and post-natal meninges and acts as a chemoattractant to embryonic neurons [40]) and CREB5.

Genes selected for validation had a fold change of $>2$ in microarray with a $P$ value of $\leq 1.0 \times 10^{-6}$. Genes showing significant changes in expression by microarray were selected based on their involvement in biological processes relevant to the inflammatory process. Our validation data confirmed the results obtained by qRT-PCR, upregulated genes by microarray were also increased by qRT-PCR analysis and genes downregulated by microarray were also decreased in qRT-PCR (Table 2, Additional file 9: Figure S7 and Additional file 10: Figure S8).

\section{Discussion}

In this study we examine the effects of inflammatory stimuli on primary adult human brain derived cells. These mixed populations of cells stain positively for microglia, astrocyte, fibroblast and pericyte markers. Since microglia and astrocytes do not normally proliferate in culture, after passaging only pericyte and fibroblast cells remain $[17,23,41]$. We hypothesize that the pericyte cells originate from the microvasculature and meninges and, in fact, we 
A

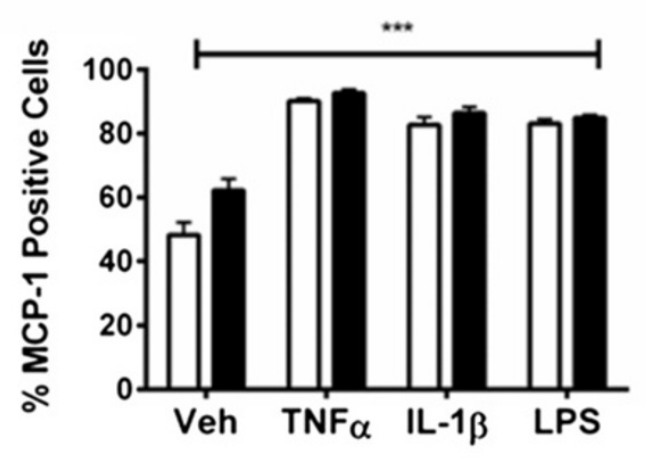

B

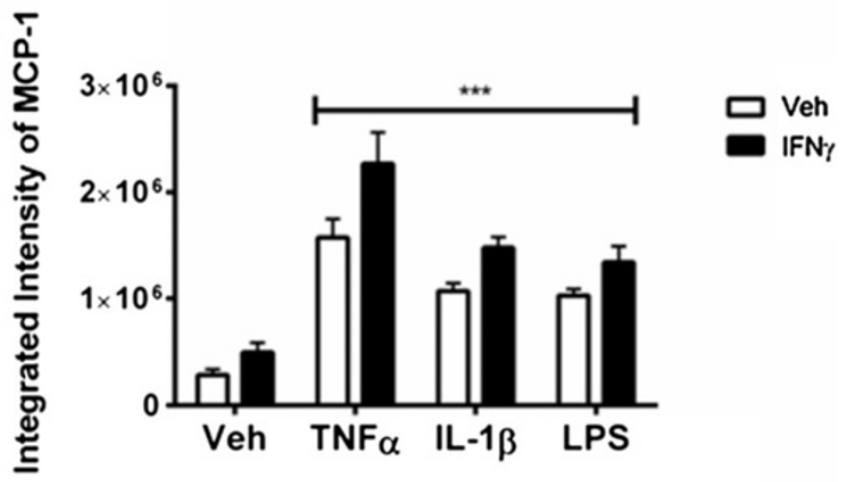

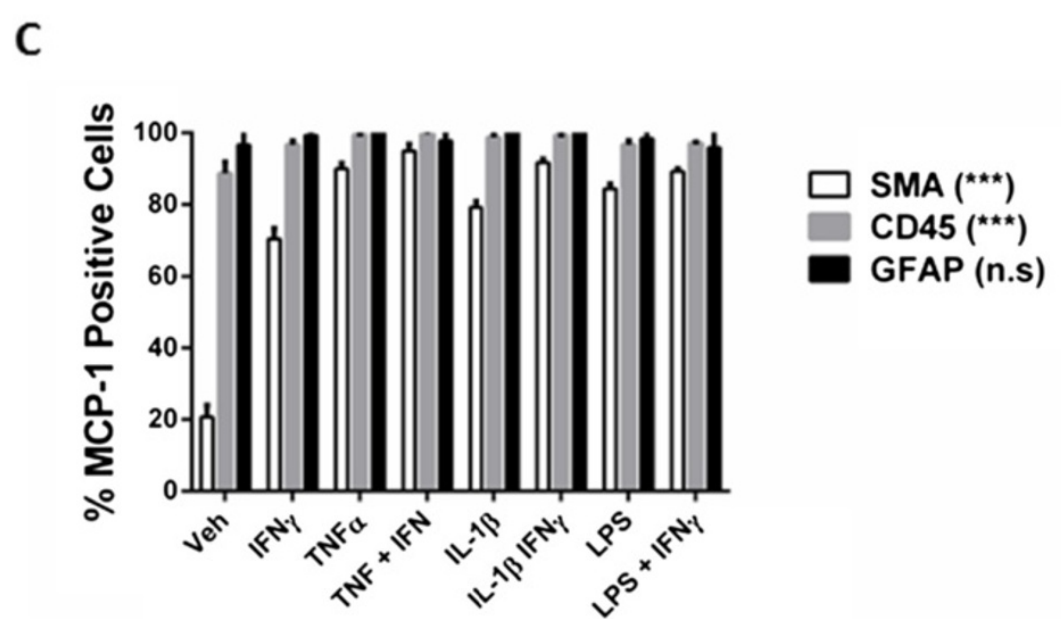

Figure 8 MCP-1 expression is increased in response to IFN $\gamma$, TNF, IL-1 $\beta$ and LPS in human mixed glial cultures. A) Quantification of MCP-1 positive cells in mixed glial cultures treated for 24 hours with vehicle $(0.1 \%$ BSA in PBS), TNFa (50 $\mathrm{ng} / \mathrm{ml})$, IL-1 3 (10 ng/ml) or LPS $(10 \mathrm{ng} / \mathrm{ml})+/-$ IFNy $(10 \mathrm{ng} / \mathrm{ml})$, from triplicate wells, at least four images per well. *indicates significance $(P<0.01)$, **indicates significance $(P<0.0001)$. Data are from one representative experiment that was repeated in three separate cases. B) Quantification of the integrated intensity of MCP-1 staining of cells treated in (A), ${ }^{* *}$ indicates significance $(P<0.0001)$. C) Quantification of the percentage of aSMA, CD45 and GFAP positive cells that express MCP-1 under conditions in $(\mathbf{A})$, ${ }^{*}$ indicates significance $(P<0.01),{ }^{* *}(P<0.001),{ }^{* *}(P<0.0001)$. GFAP, glial fibrillary acidic protein; LPS, lipopolysaccharide; MCP-1, monocyte chemotactic protein-1; aSMA, alpha smooth muscle actin.

see a consistency in cell specific markers and response to inflammatory cues in our dissociated and leptomeningeal explant cultures. Using a number of markers in this and previous studies (CD45, PU.1, GFAP), we are confident with the identification of microglia and astrocytes in our cultures $[17,26,41]$.

More recently, using markers of pericytes ( $\alpha \mathrm{SMA}$, PDGFR $\beta, N G 2$ ) and fibroblasts (P4H, fibronectin), we have been able to identify the proliferative population of cells from adult human brain cultures as a mix of brain pericytes and fibroblast-like cells. However, currently there is much debate in the literature about the in vitro identification of pericytes and, in particular, how they are distinguished (or not) from mesenchymal stem cells or fibroblasts, because there is no one specific marker for any of these cells $[42,43]$. The fact that fibronectin is detected in our cultures is in line with earlier studies as fibronectin has been shown to be expressed in pericyte cell lines [44]. Furthermore, $\alpha \mathrm{SMA}$ is expressed in pericytes at different levels dependent on the state of differentiation and treatment conditions as well as location on capillaries [36,45-47] (and unpublished observations). PDGFR $\beta$ is a more widely used marker for pericytes; however, it is also expressed in other cell types such as fibroblasts and astrocytes and can be upregulated in response to stresses such as injury and inflammation [48-50]. In double-label studies, we found that $80 \%$ to $90 \%$ of the cells (depending upon passage number) expressed both $\alpha$ SMA and PDGFR $\beta$. The other pericyte marker used here is NG2 which is a marker commonly used to identify pericytes; however, it is also present in meningeal fibroblasts and other precursor cell types [51,52]. Furthermore, we see 


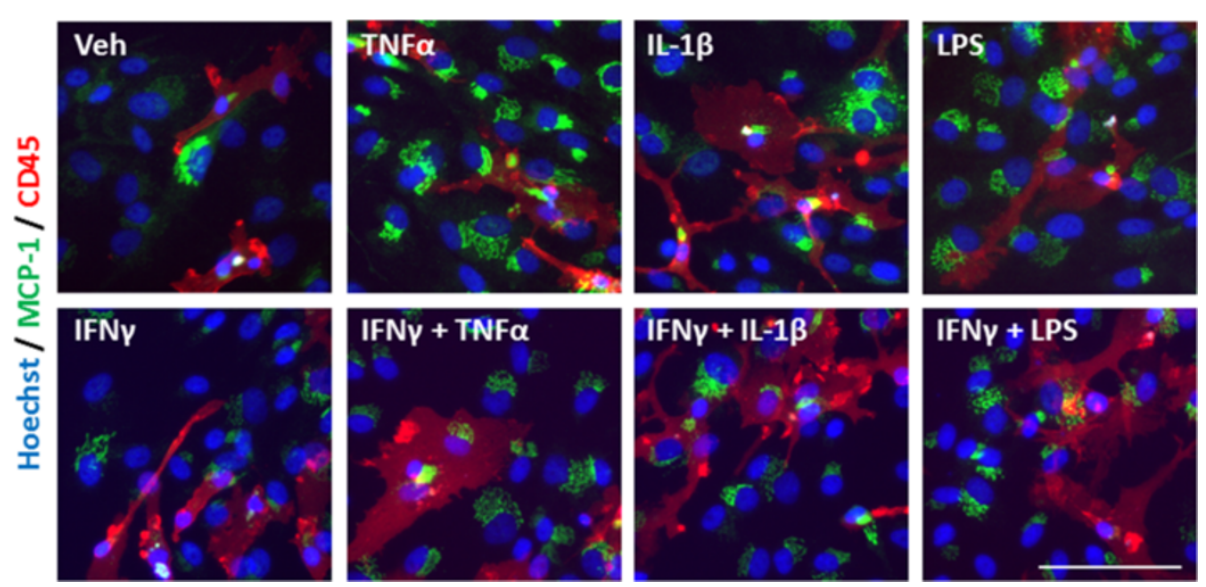

Figure 9 MCP-1 is induced in microglia in response to pro-inflammatory cues. Representative images of cells in mixed glial cultures treated for 24 hours with vehicle (0.1\% BSA in PBS), TNFa $(50 \mathrm{ng} / \mathrm{ml})$, IL-1 $3(10 \mathrm{ng} / \mathrm{ml})$ or LPS (10 ng/ml) +/- IFNy (10 ng/ml) labelled with MCP-1 (green), CD45 (red) and Hoechst (blue), scale bar $=100 \mu \mathrm{m}$. LPS, lipopolysaccharide; MCP-1, monocyte chemotactic protein-1.

a difference in NG2 band distribution by western blot when comparing pericyte cells to meningeal explant cells. This may be due to differential expression of NG2 isoforms in either cell type or due to phosphorylation events which play a role in polarity and migration $[53,54]$. For the above reasons, although we have operationally defined these cells as pericytes (based on $\alpha$ SMA, PDGFR $\beta$ and NG2 staining), it is possible that they represent a mixed cell population that may additionally contain mesenchymal stem cells and fibroblast-like cells. It is important to note that we do not see positive staining for endothelial cell markers and this may be due to the fact that we do not use any supplements specific for endothelial cell culture as in previous studies $[55,56]$.

Under our standard basal cell culture conditions, the human brain-derived microglia, astrocytes and pericytes expressed only cytoplasmic NFkB staining suggesting that these cells under our normal culture conditions are in a non-immunologically-activated state, making them a powerful system for studying human brain inflammation in vitro. To activate these cells we use cytokines IFN $\gamma$, TNF $\alpha$ and IL-1 $\beta$ as well as the bacterial endotoxin LPS, which are commonly elevated in conditions of chronic peripheral and central inflammation [57-60].

A common indicator of an inflammatory response is translocation of the transcription factor $N F \kappa B$ to the nucleus; therefore, we have used this as an initial marker of a pro-inflammatory state $[61,62]$. We have shown that both the early and late cultures will respond to inflammatory cues by inducing nuclear translocation of $\mathrm{NFKB}$ from the cytoplasm. This has been corroborated in rodent astrocytes and microglia and more recently by Guijarro-
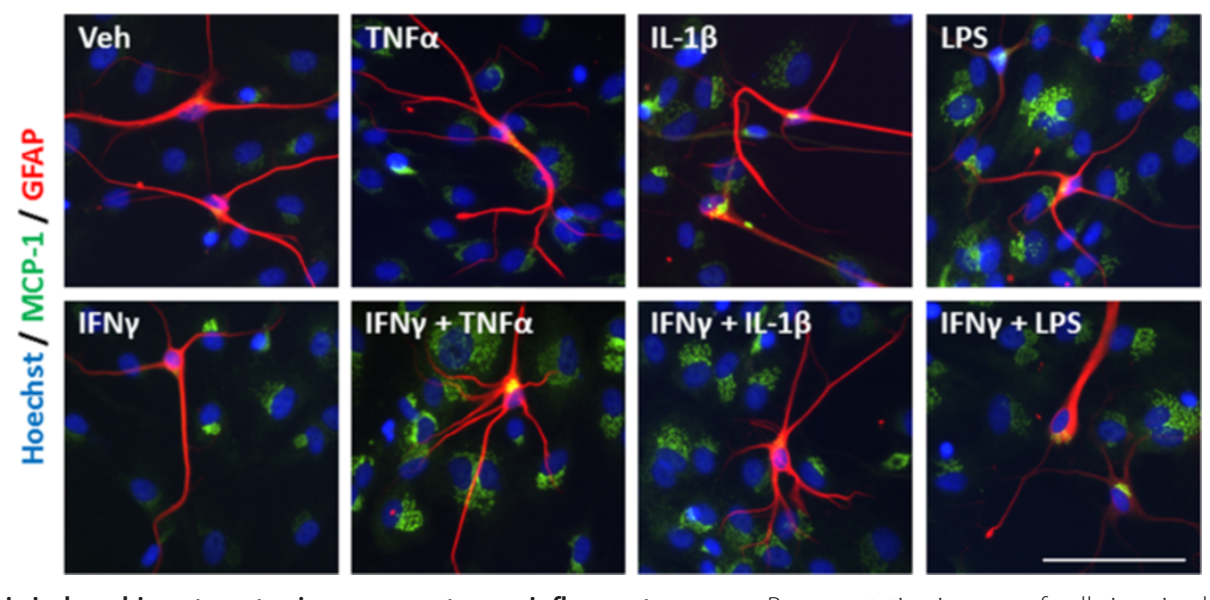

Figure $10 \mathrm{MCP}-1$ is induced in astrocytes in response to pro-inflammatory cues. Representative images of cells in mixed glial cultures treated for 24 hours with vehicle (0.1\% BSA in PBS), TNFa (50 ng/ml), IL-1ß (10 ng/ml) or LPS (10 ng/ml) +/- IFNy (10 ng/ml) labelled with MCP-1 (green), GFAP (red) and Hoechst (blue), scale bar $=100 \mu \mathrm{m}$. GFAP, glial fibrillary acidic protein; LPS, lipopolysaccharide; MCP-1, monocyte chemotactic protein-1. 

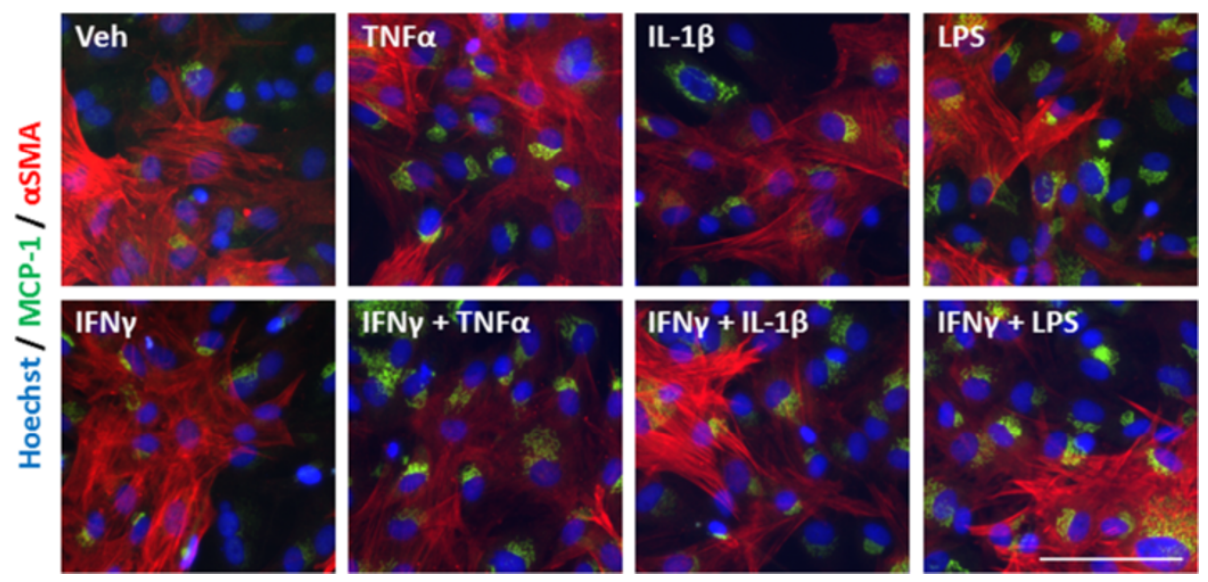

Figure 11 MCP-1 is induced in pericytes in response to pro-inflammatory cues. Representative images of cells in mixed glial cultures treated for 24 hours with vehicle $(0.1 \%$ BSA in PBS), TNFa $(50 \mathrm{ng} / \mathrm{ml})$, IL-1 $(10 \mathrm{ng} / \mathrm{ml})$ or LPS $(10 \mathrm{ng} / \mathrm{ml})+/-$ IFNy $(10 \mathrm{ng} / \mathrm{ml})$ labelled with MCP-1 (green), aSMA (red) and Hoechst (blue), scale bar = $100 \mu \mathrm{m}$. LPS, lipopolysaccharide; MCP-1, monocyte chemotactic protein-1; aSMA, alpha smooth muscle actin.

Munoz and colleagues in human pericyte cells in response to LPS $[37,63,64]$. Interestingly, we did not see this with IFN $\gamma$ treatment, which remains controversial in other studies $[65,66]$. Additionally, inhibition or blockade of the NFkB pathway has been shown to protect from LPSinduced neurotoxicity $[67,68]$. This uncovers potential targets for anti-inflammatory drug development, which is supported by in vitro evidence in human brain cells from our group and others [37].

We have also observed that pericytes upregulate protein expression of chemokines, specifically IP-10 and MCP-1 in response to various immune stimuli, and this is concentration and time-dependent. These results support previous studies using human and mouse brain pericytes showing immune activation with LPS $[29,37]$. Our studies build on and extend this previous work to show that a range of cytokines, in addition to LPS, can cause wide-spread proinflammatory immune activation of human brain pericytes.

Induced MCP-1 expression has been shown in T-cell infiltration areas and increases immune cell recruitment in animal models of central inflammation [69,70]. This may be in part due to the ability of MCP-1 to enhance permeability of $\mathrm{BBB}$ as shown in co-culture models of endothelial cells and astrocytes [71]. Increased expression of IP-10 and MCP-1 has also been implicated in MS, AD and HIV-related dementia and has been shown to induce neuronal toxicity in in vitro models $[69,72-75]$. The evidence is quite clear that these two chemokines play a role in inflammation and, possibly, neurodegeneration in the brain. Further studies examining the expression of IP-10 and MCP-1 in our human primary brain cultures will enable us to determine more precisely their role in human brain inflammation and disease.

Quantification of chemokine expression in the mixed cultures revealed a higher level of expression of IP-10 in microglia and MCP-1 in both microglia and astrocytes under basal and treated conditions compared to pericytes. Analysis of IP-10 and MCP-1 expression in the presence or absence of microglia and astrocytes has revealed similar responses by pericytes in both conditions. We see synergistic

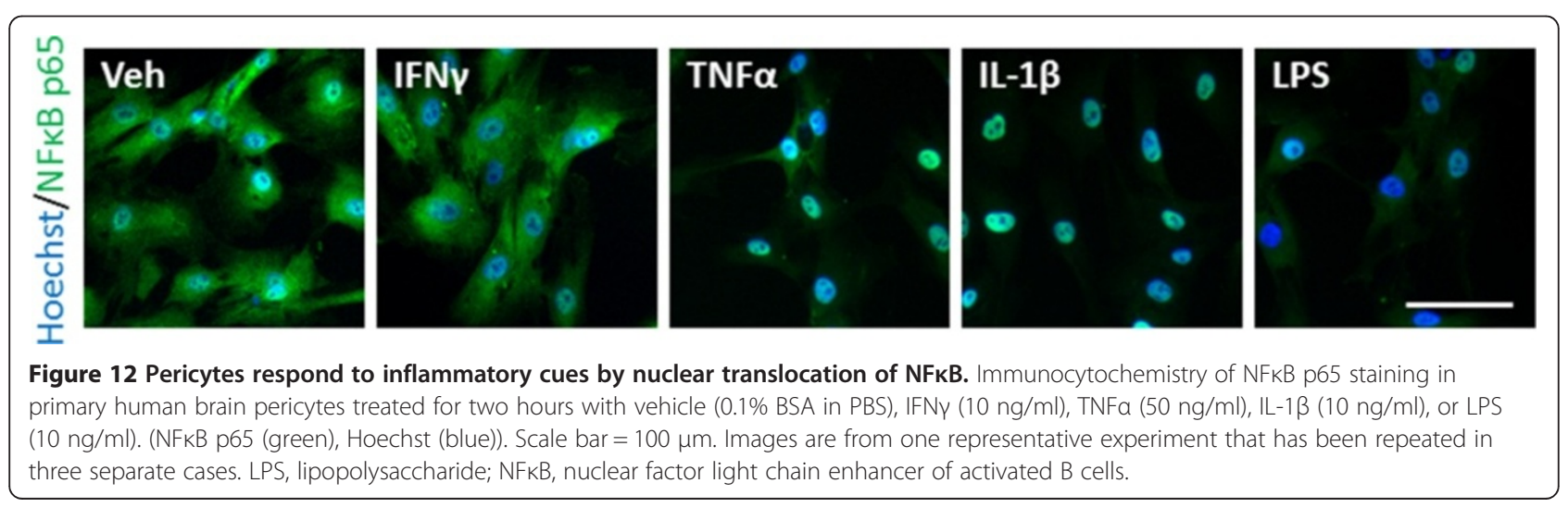



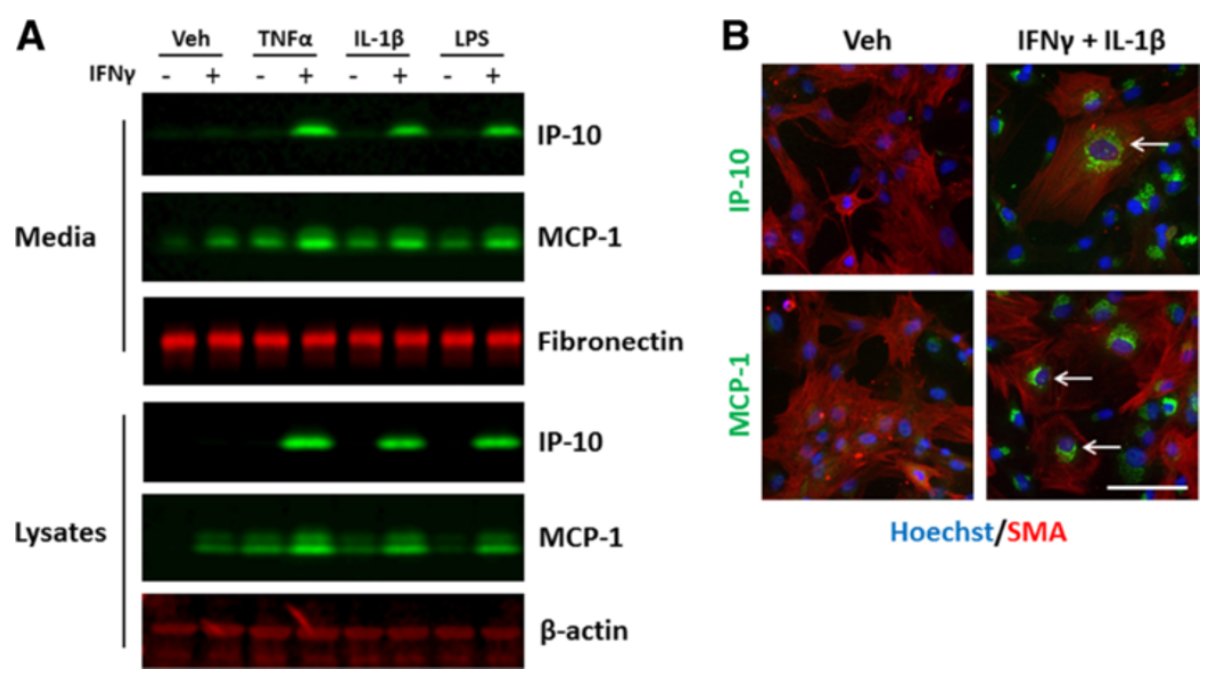

Figure 13 IP-10 and MCP-1 are expressed and secreted by primary human brain pericytes. A) Western blot analysis of media and lysates from brain pericytes treated with vehicle (0.1\% BSA in PBS), TNFa (50 ng/ml), IL-1 $\beta$ (10 ng/ml) or LPS (10 ng/ml) +/-IFNy (10 ng/ml) for 24 hours. Images are representative of experiments repeated in three separate cases. B) Immunocytochemical analysis of IP-10 and MCP-1 (both green) induction by IFNY and IL-1 $\beta$ (both $10 \mathrm{ng} / \mathrm{ml}$ ) treatment in aSMA (red) positive pericytes with Hoechst (blue) overlay. Scale bar = $100 \mu$ m. Images are representative of experiments repeated in three separate cases. IP-10, interferon inducible protein-10; LPS, lipopolysaccharide; MCP-1, monocyte chemotactic protein-1; aSMA, alpha smooth muscle actin.

induction of IP-10 in response to a combination of IFN $\gamma$ and TNF $\alpha / \mathrm{IL}-1 \beta$ or LPS by pericytes in both circumstances. However, while LPS alone induced pericyte MCP-1 expression in both conditions, IP-10 induction was only observed in early passage cultures containing microglia and astrocytes. This may be due to factors released specifically by the microglia and astrocytes themselves in response to LPS that cause IP-10 induction. Alternatively, it might be due to changes in pericytes with passaging. Further studies investigating early passage pericyte monocultures are necessary to test these possibilities.

Anatomically, pericytes surround endothelial cells and are in contact with astrocytes, neurons and other glial cells. Together these cells comprise the neurovascular unit $[76,77]$. We have shown that $\alpha$ SMA positive pericytes secrete chemokines and cytokines into media in response to pro-inflammatory cues in the absence of microglia or astrocytes. Other groups have also shown that pericytes can secrete factors that are essential for proper BBB functioning and can affect gene and protein expression in surrounding endothelial cells $[78,79]$. Coculture studies of brain pericytes and endothelial cells indicate an important role in maintenance of hemostasis as well as BBB permeability to pathogens, such as HIV-1, in human and mouse cells, respectively [80,81]. Cytokineinduced release of chemokines and other inflammatory mediators by pericytes may be able to act in an autocrine and paracrine fashion to damage cells of the neurovascular unit and disrupt the BBB. An example of this has been shown by disruption of endothelial junctions by MCP-1, which impairs proper $\mathrm{BBB}$ maintenance and functioning
$[71,82]$. Although it has been discovered that pericytes have differential roles in fetal or young compared to aged animals, these cells are essential for proper brain functioning. Loss of pericytes in mouse brain microvasculature leads to $\mathrm{BBB}$ permeability and neuronal cell death that worsens with age $[78,83]$. This is significant because BBB disruption is a feature not only of central inflammation but appears to be an early dysfunction associated with a number of neurodegenerative disorders such as epilepsy, motor neuron disease and Alzheimer's disease (reviewed [84-86]).

It is clear that pericytes play a key role in the neurovascular unit of the BBB and when performing appropriately are vital for brain cell survival. However, in circumstances such as chronic inflammation, these cells can be harmful for BBB integrity and brain function. To understand better the role of pericytes in inflammation-mediated pathologies we investigated global gene expression changes in response to pro-inflammatory cytokines in primary adult human brain pericytes. Gene hits obtained from our microarray study show increases in IFN $\gamma$-regulated genes, interleukins (IL-6, IL-8, IL-15 and IL-32) and interleukin associated receptors, which have known roles in inflammatory processes in a number of different cell types and tissues [87-92]. We also see an increase in activating transcription factor 3 (ATF3) gene expression which is activated in response to stress and may be acting as a negative feedback mechanism to inhibit IL-6 expression $[93,94]$. Indoleamine 2,3-dioxygenase (IDO-1), which regulates tryptophan metabolism, was also strongly induced in the array study. This enzyme has been implicated in immune 

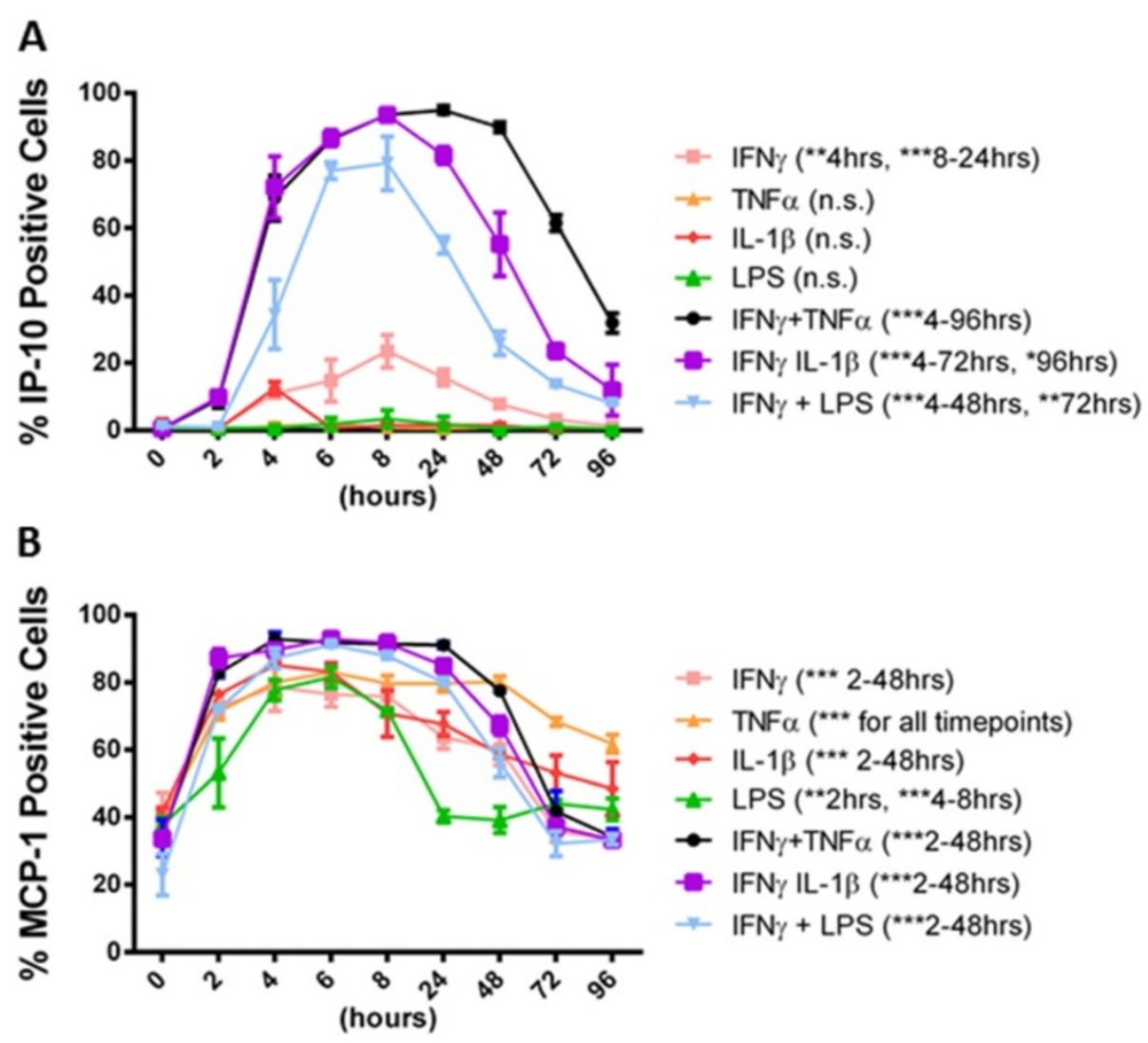

Figure 14 Time-dependent expression of IP-10 and MCP-1 in response to pro-inflammatory cytokines in adult human brain pericytes. A) Pericyte cultures treated for 0 to 96 hours with TNFa $(50 \mathrm{ng} / \mathrm{ml})$, IL-1 $1 \beta(10 \mathrm{ng} / \mathrm{ml})$ or LPS $(10 \mathrm{ng} / \mathrm{ml})+/-I F N y(10$ ng/ml), were stained by immunocytochemistry for IP-10, and Hoechst and quantified by Hoechst positive cells from triplicate wells, four images per well. *indicates significance $(P<0.01)$, ${ }^{* *}$ indicates significance $(P<0.0001)$. Data are from one representative experiment that was repeated in two separate cases. B) Pericyte cultures treated as in (A) were stained by immunocytochemistry for MCP-1 and quantified as above. IP-10, interferon inducible protein-10; LPS, lipopolysaccharide; MCP-1, monocyte chemotactic protein-1.

suppression and levels of IDO-1 are elevated in the neurofibrillary tangles of AD [95]. Chemokines IP-10 (CXCL10), CXCL11 and CXCL9 showed the largest increase by microarray, and both IP-10 and CXCL11 were validated by qRT-PCR. The role of IP-10 has been discussed; however, CXCL9 and CXCL11 are also important in peripherally mediated-CNS inflammation [6,96-98]. Interestingly CXCL9, -10 and -11 inhibit endothelial and perivascular cell growth which may contribute to BBB breakdown [99-101]. As previously mentioned, MCP-1 expression was also increased in our microarray experiment and reduces BBB integrity in in vitro and in vivo studies [71]. Rat pericytes have shown the ability to express major histocompatibility complex (MHC) class II antigen presenting molecules (such as HLA, major histocompatibility complex, class II DR alpha (HLA)) as well as intracellular adhesion molecules (ICAM) in response to IFN $\gamma$ treatment, which is consistent with our results of upregulated HLA and ICAM expression in response to cytokine treatment [102]. Particularly, ICAM may be involved in regulating immune responses by enhancing leukocyte interactions
[10]. We also observe an increase in the expression of CD74, a membrane protein that is found surrounding neurofibrillary tangles in AD [103]. Pro-apoptotic, lipid binding proteins apolipoprotein (APOL) $-1,-2,-3,-4$, and -6 were all increased in response to IFN $\gamma$ and IL- $1 \beta$ treatment which is consistent with previous work in mouse embryonic fibroblast cells [104]. Other gene hits that have been verified by qRT-PCR include interferon regulatory factor-1 (IRF1), superoxide dismutase-2 (SOD2) and prostaglandin-endoperoxide synthase-2 (PTGS2) or COX-2. IRF1 mediates mouse microglial cell death in response to IFN $\gamma$ and LPS [105]. COX-2 is often used as a marker for neuronal inflammation and has shown some beneficial effects in decreasing the risk of inflammatory mediated AD [106,107]. SOD2 dysregulation contributes to $\mathrm{AD}$ pathology in transgenic mice and neuronal cell death after ischemia [107-109]. We also see a downregulation of several genes, CXCL12, TNFRSF10D and CREB5, which were confirmed by qRT-PCR validation. CXCL12 is involved in chemoattraction but also in neuromodulation, as it affects neuronal signaling and CREB activation, and is 
Table 1 Gene ontology analysis of microarray data for pericytes treated with IFNY and IL-1 $\beta$ for 24 hours

\begin{tabular}{|c|c|c|c|}
\hline Annotation & $\begin{array}{l}\text { Total genes } \\
\text { with ann }\end{array}$ & $\begin{array}{l}\text { Genome } \\
\text { (with Ann) }\end{array}$ & Genes \\
\hline GO:0006952 [5]: defense response & 52 & 786 & $\begin{array}{l}\text { APOL2 APOL3 C1R C1S C3 C4A C4B CCL2 CCL8 CD40 CD74 CTSS } \\
\text { CXCL1 CXCL10 CXCL11 CXCL12 CXCL2 CXCL9 G1P2 GBP1 GBP2 } \\
\text { GBP5 HLA-DMA HLA-E IFI30 IFI35 IFIT3 IL15 IL18BP IL32 IL6 IL8 } \\
\text { IRF1 IRF8 MX1 NMI OAS2 OAS3 PSMB10 PSMB8 PSMB9 RIPK2 } \\
\text { SAMHD1 SERPING1 SOD2 TAP1 TAP2 TAPBP TLR3 TNFRSF14 } \\
\text { TNFSF13B UBD }\end{array}$ \\
\hline $\begin{array}{l}\text { GO:0009613 [5]: response to pest, pathogen } \\
\text { or parasite }\end{array}$ & 29 & 442 & $\begin{array}{l}\text { APOL2 APOL3 C1R C1S C3 C4A C4B CCL2 CCL8 CD40 CD74 } \\
\text { CXCL1 CXCL10 CXCL11 CXCL12 CXCL2 CXCL9 HLA-DMA IFI35 } \\
\text { IL18BP IL6 IL8 NMI PSMB10 RIPK2 SERPING1 SOD2 TLR3 UBD }\end{array}$ \\
\hline $\begin{array}{l}\text { GO:0043207 [5]: response to external biotic } \\
\text { stimulus }\end{array}$ & 29 & 473 & $\begin{array}{l}\text { APOL2 APOL3 C1R C1S C3 C4A C4B CCL2 CCL8 CD40 CD74 } \\
\text { CXCL1 CXCL10 CXCL11 CXCL12 CXCL2 CXCL9 HLA-DMA IFI35 } \\
\text { IL18BP IL6 IL8 NMI PSMB10 RIPK2 SERPING1 SOD2 TLR3 UBD }\end{array}$ \\
\hline GO:0006954 [5]: inflammatory response & 18 & 178 & $\begin{array}{l}\text { APOL3 C3 C4A C4B CCL2 CCL8 CD40 CD74 CXCL1 CXCL10 } \\
\text { CXCL11 CXCL12 CXCL2 CXCL9 IL8 NMI RIPK2 TLR3 }\end{array}$ \\
\hline GO:0009611 [5]: response to wounding & 20 & 266 & $\begin{array}{l}\text { APOL3 C3 C4A C4B CCL2 CCL8 CD40 CD74 CXCL1 CXCL10 } \\
\text { CXCL11 CXCL12 CXCL2 CXCL9 IL18BP IL8 NMI RIPK2 SOD2 TLR3 }\end{array}$ \\
\hline GO:0006959 [5]: humoral immune response & 12 & 151 & CIR C1S C3 C4A C4B CCL2 CD40 CD74 IL6 PSMB10 SERPING1 UBD \\
\hline GO:0006935 [6]: chemotaxis & 9 & 108 & CCL2 CCL8 CXCL1 CXCL10 CXCL11 CXCL12 CXCL2 CXCL9 IL8 \\
\hline GO:0006956 [6]: complement activation & 6 & 33 & CIR CIS C3 C4A C4B SERPING1 \\
\hline $\begin{array}{l}\text { GO:0006958 [7]: complement activation, classical } \\
\text { pathway }\end{array}$ & 5 & 25 & CIR CIS C3 C4A SERPINGI \\
\hline $\begin{array}{l}\text { GO:0016064 [6]: humoral defense } \\
\text { mechanism (sensu Vertebrata) }\end{array}$ & 8 & 111 & CIR CIS C3 C4A CD40 CD74 SERPING1 UBD \\
\hline GO:0042157 [7]: lipoprotein metabolism & 5 & 30 & APOL1 APOL2 APOL3 APOL4 APOL6 \\
\hline
\end{tabular}

Analysis of the top 200 gene hits including fold changes of $\geq 2$ with $P$-value $\leq 1.0 \times 10^{6}$ reveals enrichment for genes involved in inflammatory and related events.

Table 2 Gene expression changes in microarray and qRT-PCR validation

\begin{tabular}{|c|c|c|c|}
\hline Genes upregulated & Gene names & Fold change microarray & Fold change qRT-PCR \\
\hline HLA-DMA & major histocompatibility complex, class II, DM alpha & $3.70+/-0.33$ & $9.86+/-3.72$ \\
\hline ATF3 & activating transcription factor 3 & $2.33+/-1.0$ & $5.49+/-0.45$ \\
\hline ICAM1 & intercellular adhesion molecule 1 & $6.13+/-0.56$ & $80.80+/-23.88$ \\
\hline CXCL11 & chemokine (C-X-C motif) ligand 11 & $9.40+/-0.65$ & $246926+/-216491$ \\
\hline IL-6 & interleukin-6 & 5.82 & $117.69+/-17.29$ \\
\hline $\mathbb{I L}-8$ & interleukin-8 & $7.5+/-0.63$ & $193.19+/-62.31$ \\
\hline CD74 & $\begin{array}{l}\text { CD74 molecule, major histocompatibility complex, } \\
\text { class II invariant chain }\end{array}$ & $3.47+/-1.22$ & $160.96+/-142.58$ \\
\hline SOD2 & superoxide dismutase 2 , mitochondrial & $4.35+/-1.03$ & $27.38+/-3.90$ \\
\hline APOL1 & apolipoprotein L, 1 & $4.19+/-0.27$ & $25.56+/-7.87$ \\
\hline APOL2 & apolipoprotein L, 2 & 3.46 & $8.34+/-1.94$ \\
\hline RIPK2 & receptor-interacting serine-threonine kinase 2 & $2.04+/-0.25$ & $3.16+/-0.24$ \\
\hline IRF1 & interferon regulatory factor 1 & $4.48+/-0.39$ & $21.55+/-3.25$ \\
\hline PTGS2 & $\begin{array}{l}\text { prostaglandin-endoperoxide synthase } 2 \\
\text { (prostaglandin G/H synthase and cyclooxygenase) }\end{array}$ & $3.28+/-0.82$ & $8.49+/-1.09$ \\
\hline \multicolumn{4}{|l|}{ Genes downregulated } \\
\hline CREB5 & CAMP responsive element binding protein 5 & $-1.80+/-0.83$ & $0.1+/-0.03$ \\
\hline TNFRSF10D & $\begin{array}{l}\text { tumor necrosis factor receptor superfamily, } \\
\text { member } 10 \mathrm{~d} \text {, decoy with truncated death domain }\end{array}$ & -4.78 & $0.05+/-0.02$ \\
\hline CXCL12 & chemokine (C-X-C motif) ligand 12 & $-1.79+/-0.25$ & $0.39+/-0.18$ \\
\hline
\end{tabular}

Fold changes from vehicle $+/$ - SD in microarray experiment as well as qRT-PCR validation. 
involved in neurotransmitter release and modulation of voltage gated channels $[110,111]$. Several studies have indicated a protective role for CXCL12 in stroke-induced brain injury $[112,113]$. Although under our conditions and timepoints there is no evidence of cell death of pericyte cells, we do see an increase in TNFSF10/TRAIL and a decrease in TNFRSF10D expression by microarray, two genes that activate and inhibit cell death mechanisms, respectively, in response to IFN $\gamma[114,115]$. Further experiments will help to determine whether a pro-inflammatory environment will induce cell death of human brain pericytes.

In our study, we have shown that principal immune cells, such as microglia and astrocytes, are not alone in the inflammatory response as it pertains specifically to the human brain. Adult human meningeal and microvascular derived fibroblast and pericyte cells demonstrate the ability to respond to pro-inflammatory cues and activate a variety of signaling cascades to transmit a pro-inflammatory response to principal immune and other brain cells. However, caution must be used when interpreting data of this kind from in vitro cultures as culture conditions (media type, supplements added and so on) can greatly affect the physiology and biology of the cell system examined. Any information obtained from studies such as these should be verified in human tissue where possible.

\section{Conclusions}

Our studies show that human brain pericytes as well as microglia and astrocytes can generate a pro-inflammatory response after immune challenge in vitro. Drugs that reduce pericyte-mediated inflammation might be beneficial in restoring $\mathrm{BBB}$ function and reducing brain inflammation and injury in brain disorders such as epilepsy, stroke, motor neuron disease, and Alzheimer's disease, as well as many other neurodegenerative disorders.

\section{Additional files}

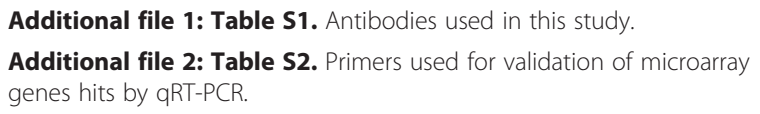

Additional file 3: Figure S1. Western blot analysis of pericyte culture extracts (P) and explant culture extracts (E) in untreated conditions confirming specificity of antibodies used for immunocytochemistry of ASMA, PDGFR- $\beta$ and NG2.

Additional file 4: Figure S2. NFKB p65 translocates to the nucleus after treatment with TNFa, IL-1 $\beta$, and LPS in microglia from mixed glial cultures. Mixed glial cultures treated with vehicle (0.1\% BSA in PBS), IFNy (10 ng/ml), TNFa $(50 \mathrm{ng} / \mathrm{ml}), \mathrm{LL}-1 \beta(10 \mathrm{ng} / \mathrm{ml})$ or LPS for two hours then stained by immunocytochemistry for NFKB p65 (green), CD45 (red), and Hoechst (blue). Scale bar $=100 \mu \mathrm{m}$. Images are representative of experiments done in triplicate, repeated in two separate cases.

Additional file 5: Figure S3. NFKB p65 translocates to the nucleus after treatment with TNFa, IL-1 $\beta$, and LPS in astrocytes from mixed glial cultures. Mixed glial cultures treated with vehicle (0.1\% BSA in PBS), IFNY
(10 ng/ml), TNFa (50 ng/ml), IL-1 $\beta(10 \mathrm{ng} / \mathrm{ml})$ or LPS for two hours then stained by immunocytochemistry for NFKB p65 (green), GFAP (red) and Hoechst (blue). Scale bar $=100 \mu \mathrm{m}$. Images are representative of experiments done in triplicate, repeated in two separate cases.

Additional file 6: Figure S4. NFKB p65 translocates to the nucleus after treatment with TNFa, IL-1 $\beta$, and LPS in pericytes from mixed glial cultures. Mixed glial cultures treated with vehicle (0.1\% BSA in PBS), IFNY $(10 \mathrm{ng} / \mathrm{ml})$, TNFa $(50 \mathrm{ng} / \mathrm{ml}), \mathrm{L}-1 \beta(10 \mathrm{ng} / \mathrm{ml})$ or LPS for two hours then stained by immunocytochemistry for NFKB p65 (green) and aSMA (red) and Hoechst (blue). Scale bar $=100 \mu \mathrm{m}$. Images are representative of experiments done in triplicate, repeated in two separate cases.

Additional file 7: Figure S5. Leptomeningeal explant cultures express IP-10 and MCP-1 and activate NFKB nuclear translocation in response to pro-inflammatory stimuli. A. Quantification of NFKB translocation in leptomeningeal explant cultures after two hours treatment with LPS $(10 \mathrm{ng} / \mathrm{ml})$, IL-1 $3(10 \mathrm{ng} / \mathrm{ml})$, or IFNy $(10 \mathrm{ng} / \mathrm{ml})$ labelled with NFKB p65. This was analyzed using Metamorph Image Analysis software (nuclear translocation assay). B. Quantification of IP-10 staining intensity in cells immunocytochemically positive for IP-10 expression after 24 hours treatment with LPS $(10 \mathrm{ng} / \mathrm{ml})$, IL-1 $\beta$ (10 ng/ml), or IFNy (10 ng/ml). C. Quantification of MCP-1 staining intensity in cells immunocytochemically positive for MCP-1 expression after 24 hours treatment LPS $(10 \mathrm{ng} / \mathrm{ml}), \mathrm{IL}-1 \beta(10 \mathrm{ng} / \mathrm{ml})$, or IFNy $(10 \mathrm{ng} / \mathrm{ml})$. Analysis is representative of experiments repeated in at least three cases.

Additional file 8: Figure S6. IP-10 and MCP-1 mRNA expression and protein secretion increases in a time-dependent manner in human brain pericyte cells. A. Western blot analysis of IP-10 and MCP-1 secretion in conditioned media from late passage primary brain cells in response to combination treatment of TNFa $(50 \mathrm{ng} / \mathrm{ml}), \mathrm{IL}-1 \beta(10 \mathrm{ng} / \mathrm{ml})$ and LPS $(10 \mathrm{ng} / \mathrm{ml})$ with IFNY $(10 \mathrm{ng} / \mathrm{ml})$. Western blot is representative of experiment repeated in two separate cases. B. qRT-PCR time-course analysis measuring IP-10 and MCP-1 gene expression in primary brain cells treated with IFNy $(10 \mathrm{ng} / \mathrm{ml})$ and $\mathrm{IL}-1 \beta(10 \mathrm{ng} / \mathrm{ml})$. Data are representative of experiment repeated in two separate cases.

Additional file 9: Figure S7. Analysis of raw data from microarray experiment of genes chosen for validation by qRT-PCR reveals significant changes in gene expression. Each graph represents raw data from microarray experiments for the genes selected for confirmation by qRT-PCR. Each point is the expression of that gene by each patient sample in the designated condition (Vehicle (Veh) or IFNY + IL-1 $\beta$ treated).

Additional file 10: Figure S8. Analysis of $\triangle \mathrm{Ct}$ values from qRT-PCR validation experiments reveals significant changes in gene expression across passages. Each graph represents mean $\Delta \mathrm{Ct}$ values for vehicle or IFNY + IL-1 $\beta$ treated cultures. This experiment was repeated three times in one case over three successive passages.

\section{Abbreviations}

AD: Alzheimer's disease; APP: amyloid precursor protein; BBB: blood brain barrier; BSA: bovine serum albumin; CSF: cerebrospinal fluid; CXCR3: chemokine CXC motif receptor 3; CCR2: chemokine cc motif receptor 2; CNS: central nervous system; CREB: cyclic-AMP response element binding protein; (D) MEM: (Dulbecco's) modified Eagle's medium; FBS: fetal bovine serum; GFAP: glial fibrillary acidic protein; ICAM: intercellular adhesion molecule; IDO-1: indoleamine 2,3-dioxygenase; HLA: major histocompatibility complex, class II DR alpha; IFNY: interferon-gamma; IP-10: interferon inducible protein-10; IL-1ß: interleukin-1 $\beta$; IKB: inhibitor of KB; LPS: lipopolysaccharide; IRF1: interferon regulatory factor-1; MCP-1: monocyte chemotactic protein-1; MHC: major histocompatibility complex; MS: multiple sclerosis; MTG: middle temporal gyrus; NFkB: nuclear factor light chain enhancer of activated B cells; PBS-T: phosphate buffered saline with Tween; PNS: peripheral nervous system; PET: positron emission tomography; PDGFRß: platelet-derived growth factor receptor- $\beta$; P4H: prolyl-4 hydroxylase; PTGS2: prostaglandin-endoperoxide synthase-2; qRT-PCR: quantitative reverse transcriptase-polymerase chain reaction; RMA: robust multi-array; SOD2: superoxide dismutase-2; SMA: smooth muscle actin; TNFa: tumor necrosis factor-a; TNFRSF10D: tumor necrosis factor receptor superfamily member 10D; TBS-T: tris buffered saline with Tween; VCAM: vascular cell adhesion molecule.

\section{Competing interests}

The authors declare that they have no competing interests. 


\section{Authors' contributions}

DJ and MD designed the experiments. DJ carried out the experiments with mixed glial and pericyte cultures as well as the microarray experiment. JR completed qRT-PCR confirmation of microarray hits including primer design and standard curves for all primers used. SF completed the leptomeningeal explant experiments and characterization. DH performed statistical analysis for the microarray study as well as general revisions of the manuscript. RLO, PSB, EWM, RLMF and MD contributed materials and edited and reviewed the manuscript. All authors read and approved the final manuscript.

\section{Acknowledgements}

We are very grateful to the tissue donors and their families for their gift of brain tissue. We are also very grateful to specialist epilepsy nurse at Auckland City Hospital Lynair Roberts for tissue collection coordination, and to the Centre for Brain Research Biobank Research Technician Inna Semenyajenko. We acknowledge the following funding bodies for their support of this research program: the Health Research Council of New Zealand, the Hugh Green Foundation,and Gravida - National Centre for Growth and Development.

\section{Author details}

'Department of Pharmacology and Clinical Pharmacology, The University of Auckland, 85 Park Road, Auckland 1023, New Zealand. ${ }^{2}$ Gravida National Centre for Growth and Development, The University of Auckland, Bldg 505, 85 Park Road, Auckland 1023, New Zealand. ${ }^{3}$ Department of Anatomy with Radiology, The University of Auckland, Bldg 505, 85 Park Road, Auckland 1023, New Zealand. ${ }^{4}$ Centre for Brain Research, The University of Auckland, Bldg 503, 85 Park Road, Auckland 1023, New Zealand. ${ }^{5}$ Department of Molecular Medicine and Pathology, The University of Auckland, Bldg 504, 85 Park Road, Auckland 1023, New Zealand. ${ }^{6}$ LabPLUS, Auckland City Hospital, Bldg 31, Gate 4 Grafton Road, Auckland 1148, New Zealand. ${ }^{7}$ Auckland City Hospital, 2 Park Rd, Auckland 1010, New Zealand.

Received: 18 December 2013 Accepted: 19 May 2014 Published: 11 June 2014

\section{References}

1. Monson NL, Ireland SJ, Ligocki AJ, Chen D, Rounds WH, Li M, Huebinger RM, Munro Cullum C, Greenberg BM, Stowe AM, Zhang R: Elevated CNS inflammation in patients with preclinical Alzheimer's disease. J Cereb Blood Flow Metab 2014, 34:30-33.

2. Aguzzi A, Barres BA, Bennett ML: Microglia: scapegoat, saboteur, or something else? Science 2013, 339:156-161.

3. Graeber MB: Changing face of microglia. Science 2010, 330:783-788.

4. Abbott NJ, Ronnback L, Hansson E: Astrocyte-endothelial interactions at the blood-brain barrier. Nat Rev Neurosci 2006, 7:41-53.

5. Paul G, Ozen I, Christophersen NS, Reinbothe T, Bengzon J, Visse E, Jansson K, Dannaeus K, Henriques-Oliveira C, Roybon L, Anisimov SV, Renström E, Svensson $M$, Haegerstrand $A$, Brundin P: The adult human brain harbors multipotent perivascular mesenchymal stem cells. PLoS One 2012, 7:e35577.

6. Alcendor DJ, Charest AM, Zhu WQ, Vigil HE, Knobel SM: Infection and upregulation of proinflammatory cytokines in human brain vascular pericytes by human cytomegalovirus. J Neuroinflammation 2012, 9:95.

7. Fabry Z, Fitzsimmons KM, Herlein JA, Moninger TO, Dobbs MB, Hart MN: Production of the cytokines interleukin 1 and 6 by murine brain microvessel endothelium and smooth muscle pericytes. J Neuroimmunol 1993, 47:23-34.

8. Dragunow M: Meningeal and choroid plexus cells-novel drug targets for CNS disorders. Brain Res 2013, 1501:32-55.

9. Winkler EA, Bell RD, Zlokovic BV: Central nervous system pericytes in health and disease. Nat Neurosci 2011, 14:1398-1405.

10. Stark K, Eckart A, Haidari S, Tirniceriu A, Lorenz M, von Bruhl ML, Gartner F, Khandoga AG, Legate KR, Pless R, Hepper I, Lauber K, Walzog B, Massberg S: Capillary and arteriolar pericytes attract innate leukocytes exiting through venules and 'instruct' them with pattern-recognition and motility programs. Nat Immunol 2013, 14:41-51.

11. Proebstl D, Voisin MB, Woodfin A, Whiteford J, D'Acquisto F, Jones GE, Rowe D, Nourshargh S: Pericytes support neutrophil subendothelial cell crawling and breaching of venular walls in vivo. J Exp Med 2012, 209:1219-1234.
12. Wang S, Cao C, Chen Z, Bankaitis V, Tzima E, Sheibani N, Burridge K: Pericytes regulate vascular basement membrane remodeling and govern neutrophil extravasation during inflammation. PLoS One 2012, 7:e45499.

13. Davalos D, Ryu JK, Merlini M, Baeten KM, Le Moan N, Petersen MA, Deerinck TJ, Smirnoff DS, Bedard C, Hakozaki H, Gonias Murray S, Ling JB, Lassmann H, Degen JL, Ellisman MH, Akassoglou K: Fibrinogen-induced perivascular microglial clustering is required for the development of axonal damage in neuroinflammation. Nat Commun 2012, 3:1227.

14. Smith AM, Dragunow M: The human side of microglia. Trends Neurosci 2014, 37:125-135.

15. Seok J, Warren HS, Cuenca AG, Mindrinos MN, Baker HV, Xu W, Richards DR, McDonald-Smith GP, Gao H, Hennessy L, Finnerty CC, López CM, Honari S, Moore EE, Minei JP, Cuschieri J, Bankey PE, Johnson JL, Sperry J, Nathens AB, Billiar TR, West MA, Jeschke MG, Klein MB, Gamelli RL, Gibran NS, Brownstein BH, Miller-Graziano C, Calvano SE, Mason PH, et al: Genomic responses in mouse models poorly mimic human inflammatory diseases. Proc Natl Acad Sci U S A 2013, 110:3507-3512.

16. De Groot CJ, Langeveld CH, Jongenelen CA, Montagne L, Van Der Valk $P$, Dijkstra CD: Establishment of human adult astrocyte cultures derived from postmortem multiple sclerosis and control brain and spinal cord regions: immunophenotypical and functional characterization. J Neurosci Res 1997, 49:342-354.

17. Gibbons HM, Hughes SM, Van Roon-Mom W, Greenwood JM, Narayan PJ, Teoh HH, Bergin PM, Mee EW, Wood PC, Faull RL, Dragunow M: Cellular composition of human glial cultures from adult biopsy brain tissue. J Neurosci Methods 2007, 166:89-98.

18. Newcombe J, Meeson A, Cuzner ML: Immunocytochemical characterization of primary glial cell cultures from normal adult human brain. Neuropathol Appl Neurobiol 1988, 14:453-465.

19. Park TI, Monzo H, Mee EW, Bergin PS, Teoh HH, Montgomery JM, Faull RL, Curtis MA, Dragunow M: Adult human brain neural progenitor cells (NPCs) and fibroblast-like cells have similar properties in vitro but only NPCs differentiate into neurons. PLoS One 2012, 7:e37742.

20. Karow M, Sanchez R, Schichor C, Masserdotti G, Ortega F, Heinrich C, Gascon S, Khan MA, Lie DC, Dellavalle A, Cossu G, Goldbrunner R, Götz M, Berninger B: Reprogramming of pericyte-derived cells of the adult human brain into induced neuronal cells. Cell Stem Cell 2012, 11:471-476.

21. Sano Y, Shimizu F, Abe M, Maeda T, Kashiwamura Y, Ohtsuki S, Terasaki T, Obinata M, Kajiwara K, Fujii M, Suzuki M, Kanda T: Establishment of a new conditionally immortalized human brain microvascular endothelial cell line retaining an in vivo blood-brain barrier function. J Cell Physiol 2010, 225:519-528.

22. Biomedical Imaging Research Unit - The Universiy of Auckland. https:// www.fmhs.auckland.ac.nz/en/sms/about/our-departments/biomedicalimaging-research-unit/microscopy-and-imaging/light-fluorescence/ molecular-devices-imagexpress.html.

23. Smith AM, Gibbons HM, Oldfield RL, Bergin PM, Mee EW, Curtis MA, Faull RL, Dragunow M: M-CSF increases proliferation and phagocytosis while modulating receptor and transcription factor expression in adult human microglia. J Neuroinflammation 2013, 10:85.

24. Wang H, Wang AX, Barrett EJ: Insulin-induced endothelial cell cortical actin filament remodeling: a requirement for trans-endothelial insulin transport. Mol Endocrinol 2012, 26:1327-1338.

25. Livak KJ, Schmittgen TD: Analysis of relative gene expression data using real-time quantitative PCR and the 2(-Delta Delta $C(T)$ ) method. Methods 2001, 25:402-408.

26. Smith AM, Gibbons HM, Oldfield RL, Bergin PM, Mee EW, Faull RL, Dragunow M: The transcription factor PU.1 is critical for viability and function of human brain microglia. Glia 2013, 61:929-942.

27. Smith AM, Graham SE, Feng SX, Oldfield RL, Bergin PM, Mee EW, Faull RL, Curtis MA, Dragunow M: Adult human glia, pericytes and meningeal fibroblasts respond similarly to IFNy but not to TGF $\beta 1$ or M-CSF. PLoS One 2013, 8:e80463.

28. Hotamisligil GS: Inflammation and metabolic disorders. Nature 2006, 444:860-867.

29. Kovac A, Erickson MA, Banks WA: Brain microvascular pericytes are immunoactive in culture: cytokine, chemokine, nitric oxide, and LRP-1 expression in response to lipopolysaccharide. J Neuroinflammation 2011, 8:139. 
30. Wu Z, Zhang J, Nakanishi H: Leptomeningeal cells activate microglia and astrocytes to induce IL-10 production by releasing pro-inflammatory cytokines during systemic inflammation. J Neuroimmunol 2005, 167:90-98.

31. Garabedian BV, Lemaigre-Dubreuil Y, Mariani J: Central origin of IL-1beta produced during peripheral inflammation: role of meninges. Brain Res Mol Brain Res 2000, 75:259-263.

32. Wang $T$, Wang BR, Zhao HZ, Kuang F, Fan J, Duan XL, Ju G: Lipopolysaccharide up-regulates IL-6R alpha expression in cultured leptomeningeal cells via activation of ERK1/2 pathway. Neurochem Res 2008, 33:1901-1910.

33. Wieseler-Frank J, Jekich BM, Mahoney JH, Bland ST, Maier SF, Watkins LR: A novel immune-to-CNS communication pathway: cells of the meninges surrounding the spinal cord CSF space produce proinflammatory cytokines in response to an inflammatory stimulus. Brain Behav Immun 2007, 21:711-718.

34. Takaki J, Fujimori K, Miura M, Suzuki T, Sekino Y, Sato K: L-glutamate released from activated microglia downregulates astrocytic L-glutamate transporter expression in neuroinflammation: the 'collusion' hypothesis for increased extracellular L-glutamate concentration in neuroinflammation. J Neuroinflammation 2012, 9:275.

35. Wilms H, Sievers J, Rickert U, Rostami-Yazdi M, Mrowietz U, Lucius R: Dimethylfumarate inhibits microglial and astrocytic inflammation by suppressing the synthesis of nitric oxide, IL-1beta, TNF-alpha and IL-6 in an in-vitro model of brain inflammation. J Neuroinflammation 2010, 7:30.

36. Pieper C, Marek JJ, Unterberg M, Schwerdtle T, Galla HJ: Brain capillary pericytes contribute to the immune defense in response to cytokines or LPS in vitro. Brain Res 2014, 1550:1-8.

37. Guijarro-Munoz I, Compte M, Alvarez-Cienfuegos A, Alvarez-Vallina L, Sanz L: Lipopolysaccharide activates TLR4-mediated NF-kappaB signaling pathway and proinflammatory response in human pericytes. J Biol Chem 2014, 289:2457-2468.

38. Burke SJ, Goff MR, Lu D, Proud D, Karlstad MD, Collier JJ: Synergistic expression of the CXCL10 gene in response to IL-1beta and IFN-gamma involves NF-kappaB, phosphorylation of STAT1 at Tyr701, and acetylation of histones H3 and H4. J Immunol 2013, 191:323-336.

39. Lalaoui N, Morle A, Merino D, Jacquemin G, lessi E, Morizot A, Shirley S, Robert B, Solary E, Garrido C, Micheau O: TRAIL-R4 promotes tumor growth and resistance to apoptosis in cervical carcinoma HeLa cells through AKT. PLOS One 2011, 6:e19679.

40. Zhu Y, Yu T, Zhang XC, Nagasawa T, Wu JY, Rao Y: Role of the chemokine SDF-1 as the meningeal attractant for embryonic cerebellar neurons. Nat Neurosci 2002, 5:719-720.

41. Gibbons HM, Smith AM, Teoh HH, Bergin PM, Mee EW, Faull RL, Dragunow M: Valproic acid induces microglial dysfunction, not apoptosis, in human glial cultures. Neurobiol Dis 2011, 41:96-103.

42. Chen WC, Park TS, Murray IR, Zimmerlin L, Lazzari L, Huard J, Peault B: Cellular kinetics of perivascular MSC precursors. Stem Cell Int 2013, 2013:983059.

43. Vandenhaute E, Dehouck L, Boucau MC, Sevin E, Uzbekov R, Tardivel M, Gosselet F, Fenart L, Cecchelli R, Dehouck MP: Modelling the neurovascular unit and the blood-brain barrier with the unique function of pericytes. Curr Neurovasc Res 2011, 8:258-269.

44. Kose N, Asashima T, Muta M, lizasa H, Sai Y, Terasaki T, Nakashima E: Altered expression of basement membrane-related molecules in rat brain pericyte, endothelial, and astrocyte cell lines after transforming growth factor-beta1 treatment. Drug Metab Pharmacokinet 2007, 22:255-266.

45. Nehls $V$, Drenckhahn D: Heterogeneity of microvascular pericytes for smooth muscle type alpha-actin. J Cell Biol 1991, 113:147-154.

46. Verbeek MM, Otte-Holler I, Wesseling P, Ruiter DJ, de Waal RM: Induction of alpha-smooth muscle actin expression in cultured human brain pericytes by transforming growth factor-beta 1. Am J Pathol 1994, 144:372-382.

47. Dore-Duffy P, Mehedi A, Wang X, Bradley M, Trotter R, Gow A: Immortalized CNS pericytes are quiescent smooth muscle actin-negative and pluripotent. Microvasc Res 2011, 82:18-27.

48. Heldin $\mathrm{CH}$, Westermark B: Mechanism of action and in vivo role of platelet-derived growth factor. Physiol Rev 1999, 79:1283-1316.

49. Reuterdahl C, Tingstrom A, Terracio L, Funa K, Heldin CH, Rubin K: Characterization of platelet-derived growth factor beta-receptor expressing cells in the vasculature of human rheumatoid synovium. Lab Invest 1991, 64:321-329.
50. Reuterdahl C, Sundberg C, Rubin K, Funa K, Gerdin B: Tissue localization of beta receptors for platelet-derived growth factor and platelet-derived growth factor B chain during wound repair in humans. J Clin Invest 1993, 91:2065-2075.

51. Morgenstern DA, Asher RA, Naidu M, Carlstedt T, Levine JM, Fawcett JW: Expression and glycanation of the NG2 proteoglycan in developing, adult, and damaged peripheral nerve. Mol Cell Neurosci 2003, 24:787-802.

52. Karram K, Chatterjee N, Trotter J: NG2-expressing cells in the nervous system: role of the proteoglycan in migration and glial-neuron interaction. J Anat 2005, 207:735-744.

53. Makagiansar IT, Williams S, Dahlin-Huppe K, Fukushi J, Mustelin T, Stallcup WB: Phosphorylation of NG2 proteoglycan by protein kinase C-alpha regulates polarized membrane distribution and cell motility. J Biol Chem 2004, 279:55262-55270.

54. Girolamo F, Dallatomasina A, Rizzi M, Errede M, Walchli T, Mucignat MT, Frei K, Roncali L, Perris R, Virgintino D: Diversified expression of NG2/ CSPG4 isoforms in glioblastoma and human foetal brain identifies pericyte subsets. PLoS One 2013, 8:e84883.

55. Bernas MJ, Cardoso FL, Daley SK, Weinand ME, Campos AR, Ferreira AJ, Hoying JB, Witte MH, Brites D, Persidsky Y, Ramirez SH, Brito MA: Establishment of primary cultures of human brain microvascular endothelial cells to provide an in vitro cellular model of the blood-brain barrier. Nat Protoc 2010, 5:1265-1272.

56. Tigges $U$, Welser-Alves JV, Boroujerdi A, Milner R: A novel and simple method for culturing pericytes from mouse brain. Microvasc Res 2012, 84:74-80.

57. Tremaroli V, Backhed F: Functional interactions between the gut microbiota and host metabolism. Nature 2012, 489:242-249.

58. Odegaard JI, Chawla A: Pleiotropic actions of insulin resistance and inflammation in metabolic homeostasis. Science 2013, 339:172-177.

59. Glass CK, Saijo K, Winner B, Marchetto MC, Gage FH: Mechanisms underlying inflammation in neurodegeneration. Cell 2010, 140:918-934.

60. Meraz-Rios MA, Toral-Rios D, Franco-Bocanegra D, Villeda-Hernandez J, Campos-Pena V: Inflammatory process in Alzheimer's Disease. Front Integr Neurosci 2013, 7:59.

61. Lentsch $A B$, Ward PA: Activation and regulation of NFkappaB during acute inflammation. Clin Chem Lab Med 1999, 37:205-208.

62. Li Q, Verma IM: NF-kappaB regulation in the immune system. Nat Rev Immunol 2002, 2:725-734.

63. Gorina R, Font-Nieves M, Marquez-Kisinousky L, Santalucia T, Planas AM: Astrocyte TLR4 activation induces a proinflammatory environment through the interplay between MyD88-dependent NFkappaB signaling, MAPK, and Jak1/Stat1 pathways. Glia 2011, 59:242-255.

64. Quan N, Whiteside M, Kim L, Herkenham M: Induction of inhibitory factor kappaBalpha mRNA in the central nervous system after peripheral lipopolysaccharide administration: an in situ hybridization histochemistry study in the rat. Proc Natl Acad Sci U S A 1997, 94:10985-10990.

65. Sizemore N, Agarwal A, Das K, Lerner N, Sulak M, Rani S, Ransohoff R, Shultz $D$, Stark GR: Inhibitor of kappaB kinase is required to activate a subset of interferon gamma-stimulated genes. Proc Natl Acad Sci U S A 2004, 101:7994-7998.

66. Shultz DB, Rani MR, Fuller JD, Ransohoff RM, Stark GR: Roles of IKK-beta, IRF1, and $\mathrm{p} 65$ in the activation of chemokine genes by interferon-gamma. J Interferon Cytokine Res 2009, 29:817-824.

67. Zhang F, Qian L, Flood PM, Shi JS, Hong JS, Gao HM: Inhibition of IkappaB kinase-beta protects dopamine neurons against lipopolysaccharide-induced neurotoxicity. J Pharmacol Exp Ther 2010, 333:822-833.

68. Lee YJ, Choi DY, Choi IS, Kim KH, Kim YH, Kim HM, Lee K, Cho WG, Jung JK, Han SB, Han JY, Nam SY, Yun YW, Jeong JH, Oh KW, Hong JT: Inhibitory effect of 4-O-methylhonokiol on lipopolysaccharide-induced neuroinflammation, amyloidogenesis and memory impairment via inhibition of nuclear factor-kappaB in vitro and in vivo models. J Neuroinflammation 2012, 9:35

69. Carrillo-de Sauvage MA, Gomez A, Ros CM, Ros-Bernal F, Martin ED, Perez-Valles A, Gallego-Sanchez JM, Fernandez-Villalba E, Barcia C Sr, Barcia C Jr, Herrero MT: CCL2-expressing astrocytes mediate the extravasation of $\mathrm{T}$ lymphocytes in the brain. Evidence from patients with glioma and experimental models in vivo. PLoS One 2012, 7:e30762. 
70. Sagar D, Lamontagne A, Foss CA, Khan ZK, Pomper MG, Jain P: Dendritic cell CNS recruitment correlates with disease severity in EAE via CCL2 chemotaxis at the blood-brain barrier through paracellular transmigration and ERK activation. I Neuroinflammation 2012, 9:245

71. Stamatovic SM, Shakui P, Keep RF, Moore BB, Kunkel SL, Van Rooijen N, Andjelkovic AV: Monocyte chemoattractant protein-1 regulation of blood-brain barrier permeability. J Cereb Blood Flow Metab 2005, 25:593-606.

72. Tanuma N, Sakuma H, Sasaki A, Matsumoto Y: Chemokine expression by astrocytes plays a role in microglia/macrophage activation and subsequent neurodegeneration in secondary progressive multiple sclerosis. Acta Neuropathol 2006, 112:195-204.

73. Sui Y, Potula R, Dhillon N, Pinson D, Li S, Nath A, Anderson C, Turchan J, Kolson D, Narayan O, Buch S: Neuronal apoptosis is mediated by CXCL10 overexpression in simian human immunodeficiency virus encephalitis. Am J Pathol 2004, 164:1557-1566.

74. Mehla R, Bivalkar-Mehla S, Nagarkatti M, Chauhan A: Programming of neurotoxic cofactor CXCL-10 in HIV-1-associated dementia: abrogation of CXCL-10-induced neuro-glial toxicity in vitro by PKC activator. J Neuroinflammation 2012, 9:239.

75. Xia MQ, Bacskai BJ, Knowles RB, Qin SX, Hyman BT: Expression of the chemokine receptor CXCR3 on neurons and the elevated expression of its ligand IP-10 in reactive astrocytes: in vitro ERK1/2 activation and role in Alzheimer's disease. J Neuroimmunol 2000, 108:227-235.

76. Nakagawa S, Deli MA, Nakao S, Honda M, Hayashi K, Nakaoke R, Kataoka Y, Niwa M: Pericytes from brain microvessels strengthen the barrier integrity in primary cultures of rat brain endothelial cells. Cell Mol Neurobiol 2007, 27:687-694.

77. Morris JG, Duffis EJ, Fisher M: Cardiac workup of ischemic stroke: can we improve our diagnostic yield? Stroke 2009, 40:2893-2898.

78. Armulik A, Genove G, Mae M, Nisancioglu MH, Wallgard E, Niaudet C, He L, Norlin J, Lindblom P, Strittmatter K, Johansson BR, Betsholtz C: Pericytes regulate the blood-brain barrier. Nature 2010, 468:557-561

79. Shimizu F, Sano Y, Abe MA, Maeda T, Ohtsuki S, Terasaki T, Kanda T: Peripheral nerve pericytes modify the blood-nerve barrier function and tight junctional molecules through the secretion of various soluble factors. J Cell Physiol 2011, 226:255-266.

80. Dohgu S, Banks WA: Brain pericytes increase the lipopolysaccharideenhanced transcytosis of HIV-1 free virus across the in vitro blood-brain barrier: evidence for cytokine-mediated pericyte-endothelial cell crosstalk. Fluids Barriers CNS 2013, 10:23.

81. Kim JA, Tran ND, Li Z, Yang F, Zhou W, Fisher MJ: Brain endothelial hemostasis regulation by pericytes. J Cereb Blood Flow Metab 2006, 26:209-217.

82. Roberts TK, Eugenin EA, Lopez L, Romero IA, Weksler BB, Couraud PO, Berman JW: CCL2 disrupts the adherens junction: implications for neuroinflammation. Lab Invest 2012, 92:1213-1233.

83. Bell RD, Winkler EA, Sagare AP, Singh I, LaRue B, Deane R, Zlokovic BV Pericytes control key neurovascular functions and neuronal phenotype in the adult brain and during brain aging. Neuron 2010, 68:409-427.

84. Winkler EA, Sengillo JD, Sullivan JS, Henkel JS, Appel SH, Zlokovic BV: Blood-spinal cord barrier breakdown and pericyte reductions in amyotrophic lateral sclerosis. Acta Neuropathol 2013, 125:111-120.

85. Erickson MA, Banks WA: Blood-brain barrier dysfunction as a cause and consequence of Alzheimer's disease. J Cereb Blood Flow Metab 2013, 33:1500-1513

86. Marchi N, Granata T, Ghosh C, Janigro D: Blood-brain barrier dysfunction and epilepsy: pathophysiologic role and therapeutic approaches. Epilepsia 2012, 53:1877-1886.

87. Indraccolo S, Pfeffer U, Minuzzo S, Esposito G, Roni V, Mandruzzato S, Ferrari N, Anfosso L, Dell'Eva R, Noonan DM, Chieco-Bianchi L, Albini A, Amadori A: Identification of genes selectively regulated by IFNs in endothelial cells. J Immunol 2007, 178:1122-1135.

88. Murakami M, Hirano T: The pathological and physiological roles of IL-6 amplifier activation. Int J Bio/ Sci 2012, 8:1267-1280.

89. Harada A, Sekido N, Akahoshi T, Wada T, Mukaida N, Matsushima K: Essential involvement of interleukin-8 (IL-8) in acute inflammation. J Leukoc Biol 1994, 56:559-564.
90. Lee MS, Kim B, Oh GT, Kim YJ: OASL1 inhibits translation of the type I interferon-regulating transcription factor IRF7. Nat Immunol 2013, 14:346-355

91. Perera PY, Lichy JH, Waldmann TA, Perera LP: The role of interleukin-15 in inflammation and immune responses to infection: implications for its therapeutic use. Microbes Infect 2012, 14:247-261.

92. Netea MG, Azam T, Ferwerda G, Girardin SE, Walsh M, Park JS, Abraham E, Kim JM, Yoon DY, Dinarello CA, Kim SH: IL-32 synergizes with nucleotide oligomerization domain (NOD) 1 and NOD2 ligands for IL-1beta and IL-6 production through a caspase 1-dependent mechanism. Proc Natl Acad Sci U S A 2005, 102:16309-16314.

93. Hunt D, Raivich G, Anderson PN: Activating transcription factor 3 and the nervous system. Front Mol Neurosci 2012, 5:7.

94. Gilchrist M, Thorsson V, Li B, Rust AG, Korb M, Roach JC, Kennedy K, Hai T, Bolouri $H$, Aderem A: Systems biology approaches identify ATF3 as a negative regulator of Toll-like receptor 4. Nature 2006, 441:173-178.

95. Bonda DJ, Mailankot M, Stone JG, Garrett MR, Staniszewska M, Castellani RJ, Siedlak SL, Zhu X, Lee HG, Perry G, Nagaraj RH, Smith MA: Indoleamine 2, 3-dioxygenase and 3-hydroxykynurenine modifications are found in the neuropathology of Alzheimer's disease. Redox Rep 2010, 15:161-168.

96. Owens GC, Huynh MN, Chang JW, McArthur DL, Hickey MJ, Vinters HV, Mathern GW, Kruse CA: Differential expression of interferon-gamma and chemokine genes distinguishes Rasmussen encephalitis from cortical dysplasia and provides evidence for an early Th1 immune response. J Neuroinflammation 2013, 10:56.

97. Wen X, Kudo T, Payne L, Wang X, Rodgers L, Suzuki Y: Predominant interferon-gamma-mediated expression of CXCL9, CXCL10, and CCL5 proteins in the brain during chronic infection with Toxoplasma gondii in $\mathrm{BALB} / \mathrm{c}$ mice resistant to development of toxoplasmic encephalitis. J Interferon Cytokine Res 2010, 30:653-660.

98. Fil D, Borysiewicz E, Konat GW: A broad upregulation of cerebral chemokine genes by peripherally-generated inflammatory mediators. Metab Brain Dis 2011, 26:49-59.

99. Lasagni L, Francalanci M, Annunziato F, Lazzeri E, Giannini S, Cosmi L, Sagrinati C, Mazzinghi B, Orlando C, Maggi E, Marra F, Romagnani S, Serio $M$, Romagnani P: An alternatively spliced variant of CXCR3 mediates the inhibition of endothelial cell growth induced by IP-10, Mig, and I-TAC, and acts as functional receptor for platelet factor 4. J Exp Med 2003, 197:1537-1549.

100. Yates-Binder CC, Rodgers M, Jaynes J, Wells A, Bodnar RJ, Turner T: An IP-10 (CXCL10)-derived peptide inhibits angiogenesis. PLOS One 2012 7:e40812.

101. Bodnar RJ, Rodgers ME, Chen WC, Wells A: Pericyte regulation of vascular remodeling through the CXC receptor 3. Arterioscler Thromb VasC Biol 2013, 33:2818-2829.

102. Balabanov R, Beaumont T, Dore-Duffy P: Role of central nervous system microvascular pericytes in activation of antigen-primed splenic Tlymphocytes. J Neurosci Res 1999, 55:578-587.

103. Bryan KJ, Zhu X, Harris PL, Perry G, Castellani RJ, Smith MA, Casadesus G: Expression of CD74 is increased in neurofibrillary tangles in Alzheimer's disease. Mol Neurodegener 2008, 3:13.

104. Wan G, Zhaorigetu S, Liu Z, Kaini R, Jiang Z, Hu CA: Apolipoprotein L1, a novel $\mathrm{BCl}-2$ homology domain 3-only lipid-binding protein, induces autophagic cell death. J Biol Chem 2008, 283:21540-21549.

105. Suk K, Chang I, Kim YH, Kim S, Kim JY, Kim H, Lee MS: Interferon gamma (IFNgamma) and tumor necrosis factor alpha synergism in ME-180 cervical cancer cell apoptosis and necrosis. IFNgamma inhibits cytoprotective NF-kappa B through STAT1/IRF-1 pathways. J Biol Chem 2001, 276:13153-13159.

106. Takechi R, Pallebage-Gamarallage MM, Lam V, Giles C, Mamo JC: Nutraceutical agents with anti-inflammatory properties prevent dietary saturated-fat induced disturbances in blood-brain barrier function in wild-type mice. J Neuroinflammation 2013, 10:73.

107. Flynn JM, Melov S: SOD2 in mitochondrial dysfunction and neurodegeneration. Free Radic Biol Med 2013, 62:4-12.

108. Esposito L, Raber J, Kekonius L, Yan F, Yu GQ, Bien-Ly N, Puolivali J, Scearce-Levie K, Masliah E, Mucke L: Reduction in mitochondrial superoxide dismutase modulates Alzheimer's disease-like pathology and accelerates the onset of behavioral changes in human amyloid precursor protein transgenic mice. J Neurosci 2006, 26:5167-5179. 
109. Jung JE, Kim GS, Chen H, Maier CM, Narasimhan P, Song YS, Niizuma K, Katsu M, Okami N, Yoshioka H, Sakata H, Goeders CE, Chan PH: Reperfusion and neurovascular dysfunction in stroke: from basic mechanisms to potential strategies for neuroprotection. Mol Neurobiol 2010, 41:172-179.

110. Meucci O, Fatatis A, Simen AA, Bushell TJ, Gray PW, Miller RJ: Chemokines regulate hippocampal neuronal signaling and gp120 neurotoxicity. Proc Natl Acad Sci U S A 1998, 95:14500-14505.

111. Guyon A, Nahon JL: Multiple actions of the chemokine stromal cell-derived factor-1alpha on neuronal activity. J Mol Endocrinol 2007, 38:365-376.

112. Hiasa K, Ishibashi M, Ohtani K, Inoue S, Zhao Q, Kitamoto S, Sata M, Ichiki T, Takeshita A, Egashira K: Gene transfer of stromal cell-derived factor-1alpha enhances ischemic vasculogenesis and angiogenesis via vascular endothelial growth factor/endothelial nitric oxide synthaserelated pathway: next-generation chemokine therapy for therapeutic neovascularization. Circulation 2004, 109:2454-2461.

113. Zemani F, Silvestre JS, Fauvel-Lafeve F, Bruel A, Vilar J, Bieche I, Laurendeau I, Galy-Fauroux I, Fischer AM, Boisson-Vidal C: Ex vivo priming of endothelial progenitor cells with SDF-1 before transplantation could increase their proangiogenic potential. Arterioscler Thromb Vasc Biol 2008 28:644-650.

114. Peng T, Zhu J, Hwangbo Y, Corey L, Bumgarner RE: Independent and cooperative antiviral actions of beta interferon and gamma interferon against herpes simplex virus replication in primary human fibroblasts. J Virol 2008, 82:1934-1945.

115. Munoz-Erazo L, Natoli R, Provis JM, Madigan MC, King NJ: Microarray analysis of gene expression in West Nile virus-infected human retinal pigment epithelium. Mol Vis 2012, 18:730-743.

doi:10.1186/1742-2094-11-104

Cite this article as: Jansson et al: A role for human brain pericytes in neuroinflammation. Journal of Neuroinflammation 2014 11:104.

\section{Submit your next manuscript to BioMed Central and take full advantage of:}

- Convenient online submission

- Thorough peer review

- No space constraints or color figure charges

- Immediate publication on acceptance

- Inclusion in PubMed, CAS, Scopus and Google Scholar

- Research which is freely available for redistribution 